\title{
A FEW KIND WORDS FOR ABSOLUTE INFRINGEMENT LIABILITY IN PATENT LAW
}

\author{
Robert P. Merges ${ }^{t}$
}

\begin{abstract}
The goal of this Article is to partially defend patent law's absolute liability rule. Most scholars question the utility of absolute liability, which makes it irrelevant whether an infringement defendant copied from the patentee or independently invented the patented invention. This Article draws from two literatures in making a defense. First, it looks to studies of how technological information is communicated or "diffused." These studies, together with research by psychologists on "inadvertent copying," demonstrate that ideas are sometimes copied in obscure and subtle ways, leaving little or no evidence that copying has indeed occurred. Next, the Article turns to the literature on optimal standards of care in tort law, which is used to describe what would happen if U.S. law changed to require patentees to show copying. Potential patent infringement defendants - a class that includes virtually all people and companies performing research and development-might well impose strict limitations on receipt of technological information. This would help rebut allegations of copying, reducing the risk of legal liability. Such strict limitations would stifle innovation because technological communities thrive on ubiquitous and unregulated communication. Patent law, as it stands, encourages communication by making proof of copying irrelevant in patent cases. As a consequence, researchers (as potential patent infringement defendants) currently have no reason to restrict their access to technical communications.

To further support the case for absolute liability, this Article looks to both copyright law and common law rules on the theft of ideas. Both require proof of copying, and both have led potential defendants to invest in restrictive measures designed to prove that they had no access to third party ideas.

By requiring only proof that the infringer is using an invention covered by the patentee's claims, patent law dispenses with the need to prove that the infringer copied from the patentee. This means that researchers have very little incentive to protect against receipt of outside information. Potential infringers get no payoff from disproving contact with a patentee because the reduced incidence of copying that would follow from lack of

DOI: http://dx.doi.org/10.15779/Z38285T

(C) 2016 Robert P. Merges.

$\dagger$ Wilson, Sonsini, Goodrich \& Rosati Professor of Law, University of California, Berkeley, School of Law. Thanks to participants in Professor Rebecca Eisenberg's IP Scholarship Seminar at the University of Michigan in 2012; to participants in the IP Scholars Conference at Berkeley in August, 2014; and, as always, to the excellent editorial assistance from the BTLJ editors and staff. I am absolutely liable for all remaining errors.
\end{abstract}


contact is irrelevant under patent law. No one invests in restricting contact, and information flows freely.

The obvious downside of the current regime is that sometimes, an infringement defendant will really be a true independent inventor; no copying, subtle or otherwise, took place. In these cases, as the literature shows, absolute liability imposes significant costs. These costs must be weighed against the benefits of information freely shared under the current absolute liability regime. It is hard to say how the costs and benefit net out. Under these circumstances, a recent innovation in U.S. patent law, the new "prior commercial use" defense under the America Invents Act (AIA), may prove helpful. This defense permits one who can prove early commercialization of an invention to avoid liability, even though he or she otherwise infringes. Because commercialization before a patentee's filing date will often be associated with independent invention, this rule reduces some of the costs of the absolute liability standard. It is difficult to say whether this combination of (1) absolute liability, plus (2) an exception for early commercialization, provides the optimal set of incentives for potential patent infringers. But at least the prior commercial use rule encourages activity that has independent social value, i.e., rapid introduction to the market. Given the real benefits to the longstanding rule of absolute liability in patent law, providing an exception under these circumstances makes for a reasonable policy.

\section{TABLE OF CONTENTS}

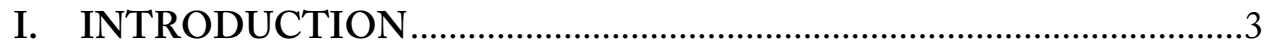

II. COPYING, DIFFUSION, AND PROBLEMS OF PROOF ...............10

A. INFORMATION DIFFUSION AND INADVERTENT

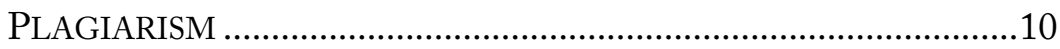

1. Diffusion Studies..................................................................11

2. Fallible Memory and Inadvertent Plagiarism............................17

B. PROVING COPYING: CASES FROM OTHER AREAS OF IP

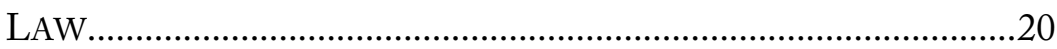

1. The Access Requirement in Copyright Law...............................21

2. Derivation in Patent Law......................................................22

C. FROM COPYING TO ACQUIRING ................................................28

III. EXCESS PRECAUTION: THE COST OF REQUIRING

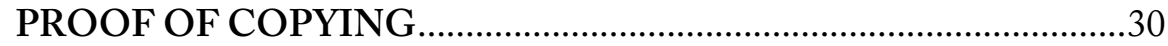

A. The TorT THEORY PERSPECTIVE ...................................................31

B. HOW ABSOLUTE LIABILITY FEEDS THE INFORMATION

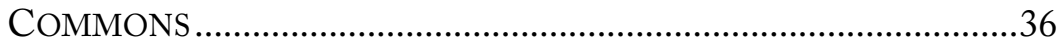

IV. PRIOR COMMERCIAL USE AND OTHER DOCTRINAL

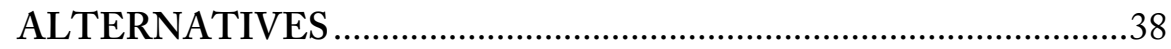

A. Prior Commercial Use: The Good And THE BAD .................38

B. Alternative “MidDLE GROUND” RulEs ....................................4

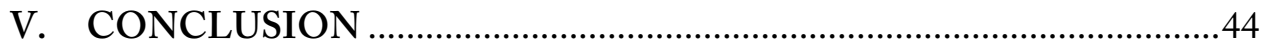




\section{INTRODUCTION}

Through its doctrinal structure, patent law essentially presumes copying on the part of any company that makes or uses technology developed after the date a patent issues. Liability follows when a product accused of infringing a patent falls within the linguistic boundaries of (at least one of) the patent's claims. It is irrelevant under current law whether the defendant actually copied the patentee's technology, let alone whether it intentionally, recklessly, negligently or inadvertently copied the patentee's technology. Put simply, patent infringement is an absolute liability regime. $^{1}$

Many commentators have decried this aspect of patent law. Absolute liability means that a patent owner can sue anyone who makes, uses, or sells the same invention covered by the patent's claims. The strong consensus on absolute liability is clear: it is a very bad idea. Most commentators agree that what patent law needs is an "independent invention" defense. ${ }^{2}$ Absolute liability, they argue, should give way to a

1. Actually, as Blair and Cotter point out, this is not completely true. That is because of the patent marking statute, which precludes the awarding of damages in cases where the patentee could have marked its product with notice of a patent, but did not. There are quirks in the marking statute that mitigate this to some extent. And also, in these cases an injunction is still possible, even in the absence of notice. See Roger D. Blair \& Thomas F. Cotter, Strict Liability and Its Alternatives in Patent Law, 17 BERKELEY TECH. L.J. 799 (2002). Also, note that this refers only to what is called direct infringement. Indirect infringement-which means that the accused party falls short of practicing every single element of a claimed invention-requires the patentee to establish that the accused infringer acted with some measure of intentionality or scienter. See Limelight Networks, Inc. v. Akamai Tech., Inc., 134 S. Ct. 2111 (2014).

2. See, e.g., Stephen M. Maurer \& Suzanne Scotchmer, The Independent Invention Defence in Intellectual Property, 69 ECONOMICA 535 (2002); Carl Shapiro, Prior User Rights, 96 AM. ECON. REV. 92 (2006); Oskar Liivak, Rethinking the Concept of Exclusion in Patent Law, 98 GEO. L.J. 1643 (2010); Samson Vermont, Independent Invention as a Defense to Patent Infringement, 105 MicH. L. REV. 475 (2006); see also Mark A. Lemley, Should Patent Infringement Require Proof of Copying?, 105 MiCH. L. REV. 1525, 1525 (2007) (identifying the primary concern with the independent invention defense as a potential reduction in incentives to invent; proposing alternatives, including prior user rights; making independent invention a defense to willful infringement; and making third party independent invention a secondary consideration weighing against nonobviousness). There are, however, a few voices that favor the status quo. But see Lemley, supra, at 1529, 1535-36 (arguing that the independent invention defense may interfere with patent law's incentive structure); John F. Duffy, Inventing Invention: A Case Study of Legal Innovation, 86 TEX. L. REV. 1, 9 (2007) ("A narrow right that allows for independent creation and protects only the precise details of a particular embodiment of the invention is unlikely to give sufficient protection, as a practical matter, to encourage the type of investments and work that society wants to encourage."); Clarisa Long, Information Costs in Patent and 
more fault-based standard. Only defendants who have copied from the patentee ought to be liable. Defendants who do not copy, who independently invent, should not be. Until the rule is changed, many observers presume that a good deal of patent litigation will be illegitimate: it pits an opportunistic patent owner against an innocent accused infringer, who learned nothing from the owner's patent because the accused party developed its technology completely independently. This means that in some sense, most cases of patent infringement can be described as rent-seeking, pure and simple-an attempt by the holder of a legal right to extract value from a company that is earning money on the basis of its own research. ${ }^{3}$ When we think of patents and rent-seeking these days, of course, it raises the specter of patent trolls. ${ }^{4}$ It is therefore

Copyright, 90 VA. L. REV. 465, 528 (2004) (arguing that "an independent creation privilege in patent law would too drastically reduce incentives to create"). From the practitioner viewpoint, see Roger Milgrim, An Independent Invention Defense to Patent Infringement: The Academy Talking to Itself: Should Anyone Listen?, 90 J. PAT. \& TRADEMARK OFF. SOC'Y 296, 297 (2008) (suggesting that academic proposals for an independent invention defense are in need of "adult supervision").

3. The alternative argument depends on a pure incentive story: inventors require an exclusive right to create and develop an expensive technology, and the benefits of exclusivity outweigh the costs of duplicative R\&D. This incentive story typically plays out in the context of a patent "race"-when two or more firms are competing to achieve a given patentable invention. See generally Suzanne Scotchmer, Incentives to Innovate, in The NeW PALGRAVE Dictionary OF ECON. \& THE LAW 273, 275 (1998) (noting "two views on patent races: that they inefficiently duplicate costs, and that they efficiently encourage higher aggregate investment"); Jennifer F. Reinganum, The Timing of Innovation: Research, Development, and Diffusion, in 1 HANDBOOK OF INDUSTRIAL ORGANiZATION 849, 853-68 (Richard Schmalensee \& Robert D. Willig eds., 1989) (also discussing literature on patent races). A related perspective quibbles with the notion that duplicate R\&D costs are really wasted. See JEAN TIROLE, THE THEORY OF INDUSTRIAL ORGANIZATION, 400 (1988) (noting that the loser in a patent race may benefit from positive spillovers, may develop another product, and may gain experience for future races); Robert P. Merges \& Richard R. Nelson, On the Complex Economics of Patent Scope, 90 COLUM. L. REV. 839, 870-79 (1990) (competition in the market for improvements spurs innovation, despite possible efficiency losses attributable to rivalrous invention).

4. There is a very large literature discussing the troll problem. For general orientation, see generally Robert P. Merges, The Trouble with Trolls: Innovation, RentSeeking, and Patent Law Reform, 24 BERKELEY TECH. L.J. 1583 (2009), and Mark A. Lemley \& A. Douglas Melamed, Missing the Forest for the Trolls, 113 CoLUM. L. REV. 2117, 2157 (2013). For information on the closely related phenomenon of the "secondary market" for patents (buying and selling patents, a practice that feeds patent troll formation and litigation), see Michael Risch, Licensing Acquired Patents, 21 GEO. MASON L. REV. 979 (2014). 
not surprising to find noted scholar Mark Lemley saying: "An independent invention defense would eliminate the troll problem."

The traditional response to this charge depends on incentive theory. A single exclusive right, it is said, reserves a product market for one firm. Under certain conditions, only this level of exclusivity can ensure an adequate return for the cost and risk of developing a complex technology. ${ }^{6}$ Absolute liability, in this setup, is required, regardless of whether several inventors might arrive at the same invention simultaneously. Put simply, a monopoly is necessary to stimulate the investment required to develop certain technologies. This is so despite the obvious double costs of this arrangement: first, due to the wasted resources that go into duplicative effort to win the "race for the patent"; and second, as a result of high consumer prices in the monopoly market resulting from the patent.

This is a plausible story theoretically. But this "need for market exclusivity" idea seems to have lost much of its power. The reason is simple enough. The story is based on two questionable assumptions: (1) very high-cost research projects that (2) culminate in a single marketcovering patent. $^{7}$ Most contemporary inventions outside the pharmaceutical context are incremental, the result of modest discrete investments made in connection with ongoing $\mathrm{R} \& \mathrm{D}$. And for this reason, in most cases today, individual patents cover but one small component, or one aspect of one component, of large, multi-component technologies. So, outside certain special cases of very high-cost research (most notably pharmaceuticals), it is difficult to make a case for exclusivity based on a single market-spanning patent.

This may well be one reason that it has become more common for patent scholars to call for proof of copying in patent law. ${ }^{8}$ The factual

5. Mark A. Lemley, Should Patent Infringement Require Proof of Copying?, 105 MiCH. L. REV. 1525, 1526 (2007).

6. See Glenn C. Loury, Market Structure and Innovation, 93 Q.J. ECON 395, 397 (1979) (modeling patent race in which "rewards ... become available only to the first firm that introduces an innovation"); Tom Lee \& Louis L. Wilde, Market Structure and Innovation: A Reformulation, 94 Q.J. OF ECON. 429, 429-30 (1980) (echoing the assumption that the race has a single winner, who obtains completely exclusive rights over all other competitors, and thus, that all other competitors lose the investments made in trying to win the race).

7. Id.

8. Trolls, or Non-Practicing Entities (NPEs) as they are sometimes called, bring most of the lawsuits they initiate in the semiconductor and computer industries, where products tend to be covered by many patents, and thus where the "race for a single dominant patent" story has the least relevance. See, e.g., Colleen V. Chien, Of Trolls, Davids, Goliaths, and Kings: Narratives and Evidence in the Litigation of High-Tech Patents, 
assumptions underlying the theoretical case for strong market exclusivity have dropped away. ${ }^{9}$ But patent law's disregard for independent invention lives on. Surely, if a single market-spanning patent is not required to call forth inventor effort and investment, then the rationale for an absolute liability regime is gone, which can only mean that it is time to do away with that regime by instituting a robust independent invention defense.

True-unless there is an alternative rationale. Is there some other plausible reason to dispense with the patentee's need to prove that the plaintiff-patentee copied its invention? Does absolute liability serve some function other than insuring complete exclusivity to the winner of a patent race?

There are two alternative rationales. First, the absolute liability rule is necessary because in some cases patentees would find it very difficult to prove copying, even though the defendant has in fact benefitted from the patentee's technological contribution. This is a tricky case to make out. It pushes against the notion that in almost every case patent infringement defendants make their inventions completely independently. Yet it assumes serious obstacles to proving just that. It is an argument rooted in notions of corrective justice: inventors should be compensated when they have bestowed benefits on others. But it also has a strong practical flavor: inventors may have trouble proving that others benefitted from their work. Thus, though the argument starts from considerations of fairness, it may be expressed in the language of a strong evidentiary presumption.

Second, absolute liability may actually encourage widespread dissemination of technical information between companies. This is obviously so in cases where a patentee can show immediate, direct, and full disclosure of an invention, together with explicit copying. But it is also true in cases where the communication is less complete, less direct, or harder to prove. Sometimes, inventions are copied somewhat inadvertently - not as the result of a clear-cut, well-planned effort to explicitly copy a competitor's product. Copying occurs, in other words, in all kinds of subtle ways. With absolute liability in place, there is no reason

87 N.C. L. REV. 1571, 1580-81 (2009) (footnotes omitted) ("NPEs have focused on high-tech inventions for several reasons. First, they have historically acquired their patents from distressed or bankrupt companies, principally casualties of the Internet bubble. Second, products in computer and semiconductor-related industries tend to be covered by many patents, increasing the likelihood of infringement.").

9. On the general trend toward thinking of large numbers of patents in "portfolios" instead of single patents, see Gideon Parchomovsky \& R. Polk Wagner, Patent Portfolios, 154 U. PA. L. REV. 1 (2005); Michael Risch, Patent Portfolios as Securities, 63 DUKE L.J. 89, 154 (2013). 
for companies to guard against either direct, complete communications from a patentee, or these more subtle forms of copying. In both cases, precautions do not matter; if a company's product infringes one or more claims of a patent, liability follows. But if an independent invention defense were introduced, this would change. Companies would be wise to change their behavior in response. A smart company would not only limit direct contact with known patentees or patent applicants. It would also begin to screen out some of the information that comes into the hands of its researchers. Screening would reduce the company's exposure to liability, by helping to show that the company's products were developed without access to outside information. By screening out incoming technical articles or other sources of external information, companies would guard against proof that they copied ideas from the technical literature, or from others in the field generally. These efforts to cut down on access would cost society a great deal. The point, developed at greater length below, is that absolute liability leaves companies with no real reason to screen out information. It encourages information sharing, and thus more innovation.

But any defense of the status quo must first engage a devastating study by Mark Lemley and Chris Cotropia, who found that patent infringement plaintiffs virtually never show actual copying on the part of a defendant, ${ }^{10}$ even when there are legal and common sense reasons why such a showing would benefit them. The study implies that the vast majority of patent infringement suits involve acts of independent invention. It suggests that the absolute liability standard in patent law is essentially the sole reason patentees are able to succeed in litigation. Is there any reason to proceed with my argument given such solid counter-evidence planted firmly in the way?

Perhaps. The Lemley and Cotropia study is not quite as devastating as it might appear at first. Their key finding is that "a surprisingly small percentage of patent cases even involve allegations of copying, much less proof of copying." 11 The authors note, of course, that patent infringement is an absolute liability regime, but they also point out a number of reasons why patentees have an incentive to prove copying. Various patent

10. Christopher A. Cotropia \& Mark A. Lemley, Copying in Patent Law, 87 N.C. L. REV. 1421 (2009) [hereinafter Cotropia \& Lemley].

11. Id. at 1422; see also id., at 1424 (reporting that copying is alleged in only $10.9 \%$ of the 193 complaints sampled; is found to have occurred in only $1.76 \%$ of the 1871 published opinions studied; and is especially rare outside the specialized context of pharmaceuticals and chemicals-for example, in cases involving computers and software, copying was found in less than $1 \%$ of the decisions studied). 
doctrines require such a showing, for instance. ${ }^{12}$ And then there is the importance of telling a good "jury story": proof of copying certainly casts the defendant in a bad light, which has to be a major advantage for the plaintiff.

Despite these advantages, the dominant fact remains that proof of copying is not essential for a plaintiff to make out its case. While it is helpful, it could also be a difficult issue to prove in many cases. True, a blatant case of copying, where the defendant bought one of the plaintiffs products on the open market, took it apart, and deliberately reverse engineered it, would likely leave a blazing paper trail. But copying happens in other ways as well. Consider a member of the defendant's research team assigned to solve one problem in the design of a new product. He or she brings to bear past experience, intuition, knowledge of the state of the art, and intelligence about competing products. In this mélange a smoking gun may not appear, or may be difficult to piece together later. Indeed, given how things really work, it might be better to sometimes say that technology is "borrowed," or "inadvertently incorporated," rather than "copied" outright. Later in this Article, the more neutral term "acquired" is used to signify this kind of less-than-blatant borrowing or copying.

Given the enormous expense of discovery in patent cases, perhaps it makes sense for the plaintiff to choose not to follow up every hint or clue that one feature or aspect of the defendant's product was derived somehow from work that owes its ultimate origin to the patentee. At a minimum, it makes sense to forgo discovery on this point when the law, in effect, already presumes that copying has taken place. Why spend resources establishing an element of a cause of action that the law already provides at the start?

From this perspective, one feature of the cases that Cotropia and Lemley criticize makes perfect sense. They note that lawyers for patentees, and sometimes courts, are prone to coyly slide from the established fact of technical claim infringement to the morally loaded language of copying, theft, and wrongdoing. ${ }^{13}$ On this point, Cotropia and Lemley are correct (and courts should guard more zealously against this subtle but influential

12. Proof of copying helps the patentee's case with respect to nonobviousness and willfulness. An infringer who copies a patentee's invention has a harder time proving that the invention was obvious, because if it were, why resort to copying? It helps with willfulness too; intentional copying is solid proof of intentionality on the part of the infringer - a key element of willful infringement. For willfulness, the incentive to prove copying is significant: willful infringement can mean up to a three-fold increase in the damages owing to the patentee.

13. Cotropia \& Lemley, supra note 10 , at 1436-37. 
slide-step). Yet the fact remains: lawyers make this move because the law invites them to. The patentee's lawyers speak of copying because the law in essence presumes it. Because lawyers do not have to establish copying affirmatively, they seldom bother to try.

So the first argument towards a tentative case for absolute liability is that the chief critique of it is not as devastating as it might appear. Cotropia and Lemley necessarily draw their data from current practice, in which proof of copying is helpful if a plaintiff happens upon it, but not in any way necessary. And this may explain at least part of the reason why copying is so seldom actually proven. Another key point mentioned above and developed below, is that there is a spectrum of information acquisition. Blatant copying is at one end, but the spectrum also includes various other forms of unacknowledged (and even unintentional) borrowing. Thus, the lack of outright copying does not mean that the accused infringer did not at some point learn something valuable from the patentee.

However, marshaling a few arguments to counter a prior study is not the same as a full refutation of it. An empirically-grounded test of the Cotropia-Lemley study, from a strictly utilitarian perspective, would include at least these data: (1) The total number of cases in which patent infringement is likely to be alleged under absolute liability and liabilityonly-with-copying; (2) the portion of each in which true, complete independent invention occurs - those cases in which the defendant learned nothing, directly or indirectly, from the patentee's research; (3) the portion of each in which some learning or benefit occurred; (4) the social welfare losses due to all patent litigation; (5) the effect on inventors' incentives, as well as total social welfare, from presuming a defendant was influenced by or benefitted from the work of the patentee, as the law does now; and (6) the social welfare differential between (a) rent-seeking litigation, under the current absolute liability regime, brought by patentees against defendants who are true and pure independent inventors; and (b) litigation where the defendant copied or at least acquired something of value from the patentee. $^{14}$

14. Mark Lemley makes an explicit connection between rent-seeking litigation and the absolute liability standard in patent law, particularly in the information technology industries. See Mark A. Lemley, Should Patent Infringement Require Proof of Copying?, 105 MicH. L. REV. 1525, 1526 (2007) (footnote omitted) ("In the information technology industries, it sometimes seems as though the overwhelming majority of patent suits are not brought against people who copied a technology, but against those who developed it independently."). 
I have a confession, reader: I don't have these data. So this Article cannot mount a comprehensive analysis of the issue. Instead, it makes a tentative start in the direction of defending the current doctrine. In essence, this Article examines whether there is anything to be said for the absolute liability standard.

\section{COPYING, DIFFUSION, AND PROBLEMS OF PROOF}

Currently, patent law's absolute liability principle allows recovery by A when $B$ incorporates into his product something of value claimed in a property right owned by A, whether or not A can prove that copying in fact occurred. Regarding the ultimate question of how many inventions are actually copied, this Article makes two claims. First, this Part will highlight how proof of copying is more difficult than one might suppose, and indeed that "copying" describes a spectrum of activities that includes but is not limited to explicit, intentional duplication. Second, Part III points out that, once proof of copying becomes relevant, researchers may respond with costly efforts to prevent the inflow of information from "outside" their own organization-with disastrous consequences for open communication and technical progress.

\section{A. INFORMATION DifFUSION AND INADVERTENT PlaGIARISM}

Over the years, scholars have discovered some fascinating things about the way technological information percolates among researchers. Some of these findings suggest that new ideas may diffuse in ways that are not highly salient, and therefore, are difficult to track. Additionally, in some related research, psychological studies have documented a persistent phenomenon called inadvertent plagiarism. When faced with a task requiring creativity, people regularly produce a piece of information they believe is original, but in fact clearly comes from someone else. ${ }^{15}$ Taken

15. One could object to deploying this literature in the patent context because of a differential in the magnitude of the information involved. Psychological studies involve recalling short bits of information-words or names. But this Article is talking about researchers on an $\mathrm{R} \& \mathrm{D}$ project, who might in some cases inadvertently "recall" entire inventions that were actually developed by and learned from others. A full claimed invention in many fields may have a significant number of technical elements. Therefore, how likely is it that someone would mistakenly create an entire invention without recalling where it came from? The answer is that the key innovative aspect of an invention may in fact be quite small. Inventions, and the patent claims that cover them, do often include numerous elements; but often only one is truly innovative-what patent lawyers call the "point of novelty." Even though an entire invention might be quite complex, the key component might involve but a small piece of technical insight. This is 
together, this research points toward a mechanism by which new technological ideas might plausibly move from one set of researchers to another. The point is that this movement can take place at a level that does not draw much explicit attention. Indeed, research in this area uses a provocative term-diffusion studies. The process is just that: diffuseextended over space and time, lacking a distinct, identifiable communicative moment. Given this mechanism, proof of copying may be very difficult to come by. In addition, even when one party in an IP case asserts that a specific idea was communicated at a distinct moment, it can be very hard to prove that such an event actually took place. This Section first describes the evidence on technological diffusion, and then turns to cases from various areas of IP law to demonstrate just how difficult it can be to prove copying in court. The upshot is that proposals for an independent invention defense seriously underestimate the difficulty of proving copying. It should be obvious that it is not enough to document every detail of an $R \& D$ project, with the hope of showing that an entire invention was developed exclusively in-house. These records would also have to trace in detail the provenance of every aspect of the project. And to be convincing, the researchers would need to show that they did not use information from any external source in devising any of the key steps in the project. If the burden was on the accused infringer to affirmatively establish independent invention, it might be a heavy burden. If, on the other hand, the burden were on the patentee to affirmatively prove copying, this would eliminate infringement liability in many situations where an accused infringer learned something valuable from an inventor, but it is hard to prove. In either case, the point is the same: the many and subtle ways information diffuses around a technical field make the entire question of independent invention/copying much more complex than it might seem. Real-world complexity, in other words, renders problematic the idea of an independent invention/lack of copying defense. The upshot is this: practical problems of proof supply a fairly strong rationale for the current absolute liability regime.

\section{Diffusion Studies}

There are three reasons to review what is known about diffusion. First, the basic premise behind arguments for an independent invention defense in patent law is that multiple firms independently create most inventions. An account of just how often firms learn of new technical information

precisely the type of information that is derived from others but misattributed to oneself in a predictable number of cases in the psychological literature. 
from various sources may help to counteract the idea that most inventions are created in "splendid isolation." Showing the ubiquity of information sharing undermines the implicit narrative of each firm as an individual research silo, separate and distinct from other firms and from the technological community as a whole.

Second, a careful description of the R\&D process will clarify the often hazy process by which technical details are learned within an organization. This may introduce some doubt into what has heretofore been a seemingly straightforward story. It is possible that researchers themselves do not always have a clear memory or understanding of the precise origin of each of the many technical inputs that go into a typical R\&D project.

The third reason relates to the mechanics of the independent invention defense. If this defense were available, as argued in Part III, it would push researchers toward a more isolationist approach to R\&D. The best way to prove independent invention is to show there was little input from the outside world into the R\&D project. Experience with "clean room" procedures, developed to avoid allegations of copying in copyright law (particularly in the computer software industry) bear this out. But this move toward "R\&D isolationism" would come at a great loss. Diffusion of information is so commonplace in technological communities that it is easy to underestimate its significance. The extensive literature on technological diffusion brings home the importance of open and liberal information flows among research specialists.

Economists, sociologists, and others have for many years been interested in the process by which information and ideas move through society. ${ }^{16}$ One branch of this subfield takes a particular interest in the diffusion of new products. Some classic studies from the late 1950s, for example, documented the spread of new types of hybrid corn through the world of agricultural research and farming. ${ }^{17}$ Another branch of the

16. For an overview of the field, see EVERETT M. ROGERS, Diffusion OF INNOVATIONS (3rd ed. 1983). For a sense of the range of phenomena that have been studied, see Henry C. Finney, American Zen's "Japan Connection": A Critical Case Study of Zen Buddhism's Diffusion to the West, 52 ReLIG. Movements \& Soc. MovemenTs 379 (1991).

17. See Zvi Griliches, Hybrid Corn: An Exploration in the Economics of Technological Change, 25 ECONOMETRICA 501 (1957); Zvi Griliches, Hybrid Corn and the Economics of Innovation, 132 SCIENCE, NEW SERIES, NO. 3422, (1960). Griliches emphasized economic incentives as the driving force behind adoption decisions, and hence diffusion rates. Forty-five years later, sociologists were still debating whether social factors, such as education level and an associated willingness to try new approaches, should also have a prominent place in explaining diffusion rates. See, e.g., Jonathan Skinner \& Douglas Staiger, Technology Adoption from Hybrid Corn to Beta Blockers (Nat'l Bureau of Econ. 
literature concentrates on the ways in which new techniques and practices in science and technology flow into academia and industry. ${ }^{18}$ Typically, studies of diffusion use aggregate measures to analyze adoption rates and diffusion patterns through industries, professions, technological communities, and entire societies over time.

Some scholars in this tradition look at the time it takes for an important innovation to be copied or duplicated by others. In his classic 1961 study on diffusion, economist Edwin Mansfield studied twelve important innovations in four industries. He found highly differential patterns of diffusion across industries: "The number of years elapsing before half the firms [in an industry] had introduced an innovation varied from 0.9 to 15 [years] . . ." 19 In a similar study, Gort and Klepper looked at 46 major product innovations between 1887 and 1960-spanning the era from the phonograph to the laser. ${ }^{20}$ They conclude: "the interval required for successful imitation has systematically declined over time." ${ }^{21}$ Average imitation time in the later examples they studied was 4.9 years, considerably less time than a full patent term (17 years during this era). This, of course, does not establish the fact of patent infringement, as duplication may be possible by inventing around, rather than actual appropriation of the claimed invention; however, it does provide some useful evidence on the general rate of diffusion.

Later studies confirm the drop in the elapsed time for information diffusion. One study from 1981 found that, within four years of patent issuance, $60 \%$ of 48 innovations in four industries had been imitated by the patentee's competitors-imitated as in copied or intentionally mimicked. ${ }^{22}$ Seventy percent of the innovations studied were patented.

Research, Working Paper No. 11251, 2005), available at http:/www.nber.org/papers/ w11251 [http://perma.cc/8UT4-2788], published at Proceedings, Federal Reserve Bank of San Francisco, http://ideas.repec.org/s/fip/fedfpr.html [http://perma.cc/TU66 -NYX3].

18. See, e.g., Thomas J. Allen, Managing the Flow of Technology: TECHNOlogy Transfer AND THE Dissemination OF TECHNOlogical INFORMATION WITHIN THE R\&D ORGANIZATION (1977).

19. Edwin Mansfield, Technical Change and the Rate of Imitation, 29 ECONOMETRICA 741, 744 (1961); see also Edwin Mansfield, The Speed of Response of Firms to New Techniques, 77 Q.J. ECON. 290 (1963) (explaining variance in firms' adoption rates as a function of their size and predicted profitability factors).

20. Michael Gort \& Steven Klepper, Time Paths in the Diffusion of Product Innovations, 92 ECON. J. 630, 638 (1982).

21. Gort \& Klepper, supra note 20, at 640.

22. See Edwin Mansfield, Mark Schwartz \& Samuel Wagner, Imitation Costs and Patents: An Empirical Study, 91 ECON. J. 907, 913 (1981). 
Those who imitated them claimed that, while patents raised the cost of imitation (by 11\%), they were able to duplicate the patented technology without, in their judgment, committing patent infringement. These claims to have "invented around" the patents were not tested in court, however. The general findings here are consistent with a later study involving 100 firms and thirteen innovations, which found that, on average, information about the commencement of development projects related to major technological innovations had "leaked out" to at least one competitor within a year. ${ }^{23}$

But what does literature on how information diffuses through technical communities have to do with the copying of inventions, and more importantly, the question of whether patent law ought to require proof of copying? Here, additional research is useful. Studies by economic sociologists establish that, within R\&D organizations, certain people are adept at "spanning boundaries" between organizations. ${ }^{24}$ These people, sometimes also called "gatekeepers," 25 acquire information from other departments or projects within an organization (i.e., a lab or company), but also from other "external" organizations, such as universities, professional societies, and related companies (vendors, customers, suppliers). ${ }^{26}$ Moreover, some boundary spanners are consulted at an aboveaverage rate for information by colleagues; these "communication stars" have been found to be "more externally oriented" than non-stars, meaning that they acquire more "general technical/scientific information," including attendance at many more professional meetings than non-stars. ${ }^{27}$ In general, according to another study, "a minority of professional employees, often called communicators, account for a majority of the information brought into and diffused throughout the organization.

23. Edwin Mansfield, How Rapidly Does New Industrial Technology Leak Out?, $34 \mathrm{~J}$. IND. ECON. 217, 217 (1985) ("II]nformation concerning the detailed nature and operation of a new product or process generally leaks out within about a year.").

24. Michael L. Tushman \& Thomas J. Scanlan, Characteristics and External Orientations of Boundary Spanning Individuals, 24 ACAD. OF MGMT. J. 83 (1981).

25. Michael L. Tushman \& Ralph Katz, External Communication and Project Performance: An Investigation into the Role of Gatekeepers, 26 MGMT. SCI. 1071, 1071, 1073 (1980) ("[G]atekeepers are able to gather and understand external information, and subsequently they are able to translate this information into terms that are meaningful and useful to their more locally oriented colleagues.").

26. Tushman \& Scanlan, supra note 24, at 86 ("Extra-organizational communication [in this study] was further separated into professional (universities, professional societies) and operational (suppliers, vendors, customers) areas.").

27. Tushman \& Scanlan, supra note 24 , at 88 (text and Table 1, "Technical/Trade Meetings" column). 
Communicators are well-connected to information sources outside and inside the organization." 28 The study found that high communicators were major contributors to innovative ideas within the organization. ${ }^{29}$

The reason these technical $R \& D$ professionals are valued is that they are good at gathering information from outside a particular lab or project group and orally communicating it to others within the group. ${ }^{30}$ They help others solve problems. They are repositories of useful information gleaned from a wide network of contacts. There is no record of these informal consultations. Information flows freely without any documentation. That is why these communicators are effective: they know a lot, learned from many sources, and can translate this knowledge into terms immediately useful to their peers.

The significance of this well-documented communication pattern is clear: within technological communities, ideas flow freely across organizational boundaries. And it means that the provenance of an idea may be obscured or lost in this process. Put simply, no one might remember where a particular piece of technical information originated. All that matters is learning the relevant solution that is required and plugging this solution into a particular problem. An alternative scenario, explored in depth by Professor Eric von Hippel of MIT, is where engineers at rival companies "informally" exchange proprietary information in a professional peer network. ${ }^{31}$ In this case, no records are kept precisely because the engineers involved do not want to leave a "paper trail."

28. Robert T. Keller \& Winford E. Holland, Communicators and Innovators in Research and Development Organizations, 26 ACAD. MGMT. J. 742, 742 (1983).

29. Id. at 742 .

30. See, e.g., Michael L. Tushman \& Thomas J. Scanlan, Boundary Spanning Individuals: Their Role in Information Transfer and Their Antecedents, 24 ACAD. MGMT. J. 289. 294 (1981), (noting study protocol: recording reports of oral communication among R\&D personnel).

31. Eric von Hippel, Cooperation Between Rivals: Informal Know-How Trading, 16 RES. POL'Y 291, 291 (1987) (Finding “a novel type of cooperative R\&D: the informal trading of proprietary know-how between rival (and non-rival) firms. I have observed this behavior to be widespread in [the steel 'minimill' industry] . . . [but] it may be present in many industries."). In this study, von Hippel builds on an earlier landmark paper studying instances of informal knowledge-sharing among members of technical communities. See Robert C. Allen, Collective Invention, 4 J. ECON. BEHAV. \& ORG. 1 (1983) (defining "collective invention" as invention growing out of the interaction between technical employees of multiple companies; and stating that " $[\mathrm{t}]$ he essential precondition for collective invention is the free exchange of information about new techniques and plant designs among firms in an industry"). Allen found that the iron industry in Britain between 1850 and 1875 was constituted so that collective invention took place in the area of iron blast furnace design. Id. at 3. 
Consider also a study of engineering research labs, primarily in the electronics and aerospace industries, which provides evidence that formally written-down ideas may at times be borrowed without proper credit. In this study of a 36 member R\&D team, author Thomas Allen found that informal engineering reports, produced by engineers mostly in external private companies, and circulated among various research teams within a company, were a major source of engineering information. ${ }^{32}$ But these reports changed hands constantly:

[External reports] are necessarily limited in number [of copies] on the one hand and widely needed on the other, resulting in a situation in which they are passed back and forth among colleagues over the course of a project. ... [T] [Tere is a body of informal documentation that is in a state of constant flow within the laboratory. In this way, a single report very likely reaches a fairly large audience in a short period of time. ${ }^{33}$

Allen kept track of all reported communications between individuals on the team he studied. Most importantly, he found discrepancies among pairs of researchers with regard to the number of times they communicated with each other.

[Person A], for instance, reported communication with $[\mathrm{B}]$ more often than $[\mathrm{B}]$ acknowledged communicating with [A]. There are a number of possible reasons for this difference. Some people have better memories; others are more careful in responding to questionnaires [such as those used in the study]. There is a slight tendency for the lower-status member of a communication pair to be more likely than the higher-status member to remember a transaction. ${ }^{34}$

This study reflects two things that are highly useful to the task at hand: first, some information is "in a state of constant flow" within an organization; and second, not everyone remembers communications about specific pieces of information.

Jaffe et al. observed a similar pattern in a study of knowledge diffusion out of a NASA research lab, the Electro-Physics Branch (EPB) of the

32. Allen, supra note 18.

33. Id.

34. Allen, supra note 18 , at 143 . There is a sense in this passage that social hierarchy may play a role, not only in memory, but also in patterns of attribution. This is closely related to ethnographic and sociological studies of the conduct of science. See generally Bruno Latour \& STEve WoOlgar, Laboratory Life (1979); DominiQue Vinck, The Sociology of ScIENTIFIC WORK 51 (2010) (describing research on hierarchies in science). 
NASA-Lewis Research Center in Cleveland. ${ }^{35}$ This study carefully tracked interactions between members of the lab and outside organizations to investigate the relationship between patent citations and information transfer, or "spillover." This necessitated an inquiry into interactions between lab members whose patents cited the work of other organizations; the question was, did the citations indicate a high degree of interaction and communication? In the course of the study, however, the investigator discovered a number of occasions where close contact did not lead to a citation, even though it might have been expected to do so. The authors concluded: "It is also clear that contact can occur and not generate any citations: 18 patents were found in the general area of EPB's research by organizations that had had significant contact with EPB but that did not cite the EPB patents." ${ }^{36}$ Thus the inflow of information from EPB to these other organizations was never documented. There was no record that EPB ideas and information were acquired by these other organizations. Diffusion without documentation-this provides the key rationale for dispensing with proof of copying.

Thus, when it comes to diffusion of ideas, the higher the rate of information flow the less likely that any single piece of information will receive formal credit, or even be recalled later. High throughput probably explains most occasions when diffusion occurs, but credit or citations are omitted. The next Section, on fallible memory and its close cousin, inadvertent plagiarism, explores one pathway through which this can occur.

\section{Fallible Memory and Inadvertent Plagiarism}

First consider the all-too-human possibility of a fallible memory ${ }^{37}$ In their study of patents cited in other patents, and the degree to which cited patents demonstrate actual information diffusion ("spillover score"), Jaffe et al. found that:

35. Adam B. Jaffe, Michael S. Fogarty \& Bruce A. Banks, Evidence from Patents and Patent Citations on the Impact of NASA and Other Federal Labs on Commercial Innovation, 46 J. INDUS. ECON. 183 (1998).

36. Id. at 197.

37. Students of copyright law will note right away the similarity between the ideas discussed here and copyright cases on "subconscious copying." See, e.g., Bright Tunes Music Corp. v. Harrisongs Music, Ltd., 420 F. Supp. 177, 180-81 (S.D.N.Y. 1976) (finding that George Harrison subconsciously copied his song "My Sweet Lord" from an earlier song called "He's So Fine"); see also Carissa L. Alden, A Proposal to Replace the Subconscious Copying Doctrine, 29 CARDOZO L. REV. 1729 (2008) (collecting cases; suggesting that the doctrine as applied makes it too easy for copyright holders to establish liability). 
[T] he spillover score [in cited patents] is higher if the cited patent is more recent. ... For the citations, this is consistent with more recent patents being more useful and older citations being more likely to be nonspillovers included by the lawyer or examiner. It could also reflect the possibility that the inventor's memory of actual communication is better with respect to more recent technology. ${ }^{38}$

Experimental psychologists call this general phenomenon implicit memory, or cryptomnesia. The latter term is defined as "generating a word, an idea, a song, or a solution to a problem with the idea that it is either totally original, or at least original within the present context." ${ }^{39}$ Cryptomnesia relates to the findings of an extensive literature on the psychological phenomenon of "inadvertent plagiarism." Studies with experimental subjects routinely show that people in a small but appreciable number of cases will provide information they believe is original to them, but that has in fact been derived from another source. Commonly, these studies provide an original list of information, either from a group session or via a computer. Then participants are asked to supply new pieces of information in the general category of the original information supplied (e.g., types of sports, words beginning with the letters "BE"). A small but persistent percentage of people give as new information things that were supplied in the original list. And, interestingly, the effect is amplified by a delay between the information-supply phase and the new-information phase of the study. There is little evidence that the subjects are liars; researchers consistently conclude that the subjects really believe they are the origin of the information. ${ }^{40}$

38. Adam B. Jaffe \& Manuel Trajtenberg, Patents, Citations, and INNOVATIONS: A WINDOW ON THE KNOWLEDGE ECONOMY 394 (2005).

39. Alan S. Brown \& Dana R. Murphy, Cryptomnesia: Delineating Inadvertent Plagiarism, 15 J. EXPerimental Psychol.: LEARNING, MEMORY, \& Cognition, 432, 432 (1989).

40. See, e.g., Brown and Murphy, supra note 39; Patricia L. Tenpenny, Maria S. Keriazakos, Gavin S. Lew \& Thomas P. Phelan, In Search of Inadvertent Plagiarism, 111 AM. J. PsYCHOL. 529 (1998); Richard L. Marsh \& Joshua D. Landau, Item Availability in Cryptomnesia: Assessing its Role in Two Paradigms of Unconscious Plagiarism, $21 \mathrm{~J}$. EXPERIMENTAL PSYCHOL.: LEARNING, MEMORY, \& COGNITION, 1568 (1995); Richard L. Marsh \& Gordon H. Bower, Eliciting Cryptomnesia: Unconscious Plagiarism in a Puzzle Task, 19 J. EXPERIMENTAL PSYCH.: LEARNING, MEMORY, \& COGNITION, 673 (1993). In a related set of experiments, researchers found that when told of a striking event experienced by another, people will sometimes incorporate that event or something similar into their own autobiography. See Alan S. Brown \& Elizabeth J. Marsh, Evoking False Beliefs About Autobiographical Experience, 15 PsYCHONOMIC BulL. \& REV. 186, 186 (2008). 
One early contributor to this literature described the phenomenon at work in fields requiring creativity:

When an event consists of information about some original creation in the world of art, literature and thought, and the logical memory of the event has deteriorated to the point at which the information is no longer recognized as a memory, cryptomnesia may give rise to unintended plagiarism. This happens when the logical memory is activated fortuitously or by some mental scanning process so that the information appears in consciousness as a cryptomnesically unfamiliar train of thought whose originality and value is appreciated. The train of thought may then be proudly, though mistakenly, claimed as a personal creation. ${ }^{41}$

A substantial body of research shows that many pieces of technical information are transmitted over distance in various ways, usually without direct personal contact. For example, there is some very instructive research on the origins and significance of patent citations. Adam Jaffe and Manuel Trajtenberg, in their monograph on patent citations and spillovers, found that patent citations are generally an effective, albeit "noisy," indicator of spillovers. In other words, many citations are evidence that real information changed hands. Of immediate interest is their finding, based on extensive interviewing of researchers, that only $18 \%$ of patents cited by inventors stem from interpersonal interactions with other researchers. ${ }^{42}$ What about the other $82 \%$ ? These, possibly, are the product

41. F. Kräupl Taylor, Cryptomnesia and Plagiarism, 111 BRIT. J. PsYCHIATRY. 1111, 1112-13 (1965) (emphasis in original). Taylor goes on to provide several examples involving Freud and Nietzshe (discovered by Jung). Id. at 1113.

42. Jaffe \& Trajtenberg, supra note 38, at 390. Interpersonal interaction is an important diffusion mechanism. See, e.g., AlAn HydE, WORKING IN SILICON VALlEY: ECONOMIC AND LEgal ANALYSIS OF A HIGH-VELOCITY LABOR MaRKET XVII (2003) ("When the workforce is mobile, people know what is happening in other shops. Even temporary employees know useful things about how other firms in the industry do things."). More generally, Jaffe \& Trajtenberg report that $28 \%$ of inventors had "high familiarity" with the patents they cite. Jaffe \& Trajtenberg, supra note 38, at 389 . Of course, patent lawyers add many patent citations during the preparation of patent applications. The point is simply that there is a lot of technical information that flows to researchers in highly diffuse and generalized ways, and that it is the exception rather than the rule that direct personal knowledge and attribution are involved, even when a patent is cited. And, as the studies on inadvertent plagiarism show, people are loathe to give credit-either because they do not think it is due, or because it will detract from the credit they themselves would receive. See, e.g., James B. Gambrell, The Impact of Private Prior Art on Inventorship, Obviousness, and Inequitable Conduct, 12 FED. CIR. B.J. 425, 448 (2002-2003): 
of the many diverse and subtle diffusion mechanisms existing in technological communities: word of mouth, formal instruction, tacit knowledge picked up but not really remembered. Lack of direct interpersonal copying does not mean that someone who worked on an $\mathrm{R} \& \mathrm{D}$ project did not borrow ideas from an earlier inventor. There is a great gap between pure, unmediated invention and outright slavish copying. Patent law seeks to fill this gap by dispensing with proof of actual copying. And this, in turn, is embodied in the doctrine of absolute liability for patent infringement.

\section{B. Proving COPYING: CASES From Other AREAS OF IP LAW}

Intellectual property doctrines, such as subconscious copying in copyright law, demonstrate that there can be copying or borrowing, even when it is difficult to prove. This Section draws evidence for this assertion from various areas of intellectual property law where proof of copying is required, or at least relevant. The two most important areas are (1) copyright, where independent creation is a defense and therefore copying of some kind must be proven; and (2) the derivation defense in patent law, which allows someone accused of infringing a patent to prove that the patented invention was copied (or "derived," to use the polite patent term) from another person. A quick tour through these areas of IP law shows just how difficult it can be to prove actual copying conclusively. Copyright law settles for proof of what might be called "an opportunity to copy" in most cases; ${ }^{43}$ and in cases of "striking similarity," it sometimes dispenses completely with the need to prove the copier had "access" to the original. Moreover, under patent law's derivation defense, the cases show how hard it can be to establish copying, even with solid evidence of extensive contact

When the issue of $\S 102(\mathrm{f})$ prior art surfaces during litigation to enforce a patent, the problems get more complicated.... [T] discover some possible $\S 102(\mathrm{f})$ prior art in searching through its documents or as a result of detailed discussions with the inventors named on the patent and their professional counterparts. However the presence or possibility of $\S 102(\mathrm{f})$ prior art becomes an issue in the litigation, it is a complication that must be addressed by the patentee and his assignee. The first step is straightforward-be candid with your opponent and up front with the court. The reflex is to Deny! Deny! And Deny! This is a bad strategy and a shortsighted policy.

43. Melville Nimmer \& DAVID Nimmer, 4 Nimmer ON COPYRIGHT, $\S 13.02[\mathrm{~A}]$ (footnote omitted) (" $[\mathrm{I}] \mathrm{t}$ is clear that, even if evidence is unavailable to demonstrate actual viewing, proof that the defendant had the opportunity to view (when combined with probative similarity) is sufficient to permit the trier to conclude that copying as a factual matter has occurred ... perhaps the more prevailing definition of access [is] . . the opportunity to copy.”). $I d$. 
between an original inventor and an allegedly deriving patentee. Taken together, copyright and derivation demonstrate that proof of copying is no simple matter. While this cannot constitute a sufficient reason to adopt absolute liability, it should at least give pause to those who claim the obvious superiority of requiring proof of copying in patent law. The difficulty and complexity of the copying issue is an argument favoring absolute liability - at least for anyone concerned that copying takes place in a fair number of cases where proof is elusive. ${ }^{44}$

\section{The Access Requirement in Copyright Law}

Judges recognize that inadvertent plagiarism can be the source of duplicated ideas. Though patent case law has occasionally appreciated this phenomenon, ${ }^{45}$ the clearest example is the "subconscious copying" doctrine, which has been around in U.S. copyright law for many years. In general, copyright law requires a copyright owner to establish proof of access and substantial similarity. If the copyright owner cannot show the accused infringer had access to the copyrighted work, there is a high likelihood that the accused infringer independently created his or her work.

Yet copyright cases show a healthy respect for the difficulty of directly proving access. Courts will often infer access on the basis of circumstantial evidence. $^{46}$ But even when a copyrighted work has been widely disseminated, it may be difficult to show that a particular defendant had actual access. One way to deal with this problem is by determining the degree of similarity between the copyrighted work and the accused infringement. If they are "strikingly similar," some courts are willing to infer access without more. ${ }^{47}$ In other cases, however, courts have developed

44. Indeed, one's attitude toward this issue bears heavily on how one views absolute liability. If undetected copying is a very large concern, then it makes sense to design the legal system to prevent this serious wrong in as many cases as possible-thus, absolute liability. But if, on the other hand, one is more concerned with imposing liability on someone who has independently invented, then a few cases of actual yet unproven copying may seem well worth the cost. As is so often true in IP law, the empirical questions are well nigh intractable, and when confronted with a tough case we may resort to policy arguments based on rights-based theories of IP or fairness/distributional considerations. $C f$. Robert P. Merges, Justifying InTELleCtUAL PROPERTY (2011).

45. See, e.g., Barrett v. Hall, 2 F. Cas. 914, 924 (No. 1047) (C.C.D. Mass. 1818) ("[A] party may innocently mistake, as to the extent of his own claims. . . [A] party may suppose, that he has invented, what in truth has been partly suggested by another mind.").

46. See, e.g., Mark A. Lemley, Our Bizarre System for Proving Copyright Infringement, 57 J. COPYRIGHT SOC'Y U.S.A. 719, 720-21 (2009-2010). See generally Pamela Samuelson, A Fresh Look at Tests for Nonliteral Copyright Infringement, 107 NW. U. L. REV. 1821, 1824 (2013) (describing time-honored tests for nonliteral infringement).

47. See, e.g., Three Boys Music Corp. v. Bolton, 212 F.3d 477, 484 (9th Cir. 2000). 
the doctrine of "subconscious copying." ${ }^{8}$ Given a high degree of similarity, plus a showing of an "opportunity to copy," courts infer access and conclude that the copyrighted work lodged in the infringer's unconscious, only to emerge later at the infringer's putative moment of creation. The doctrine has a long history in copyright law, going back at least to Judge Learned Hand in the 1920s. ${ }^{49}$ It continues to evolve, and cause controversy. ${ }^{50}$

Subconscious copying bears a close resemblance to the results of extensive studies on inadvertent plagiarism. The cases and the studies certainly suggest a plausible mechanism by which copying or borrowing may occur. And there is no reason why it should be any less common in technology fields covered by patents than in creative fields governed by copyright law. In this light, patent law's absolute liability standard might be defended yet again. In cases where borrowing occurs but is hard to prove, absolute liability serves the same function as the doctrine of subconscious copying in copyright law. It establishes liability even where direct evidence of copying is not available.

\section{Derivation in Patent Law}

a) Full Derivation (35 U.S.C. § 102(f))

Obviously, all sorts of learning and information exchange occur in settings other than face-to-face meetings. Yet in virtually every reported case on the issue, claims of derivation involve a face-to-face meeting of some kind. This is in large part a function of the standard of proof in derivation cases. The person trying to invalidate a patent by asserting derivation must show both (1) a prior conception of the later-claimed invention (i.e., conception by the "derivee"), and (2) that this complete

48. See, e.g., ABKCO Music, Inc. v. Harrisongs Music, Ltd., 722 F.2d 988 (2d Cir. 1983).

49. See Fred Fisher, Inc. v. Dillingham, 298 F. 145, 147-48 (S.D.N.Y.1924) (L. Hand, J.) ("Everything registers somewhere in our memories, and no one can tell what may evoke it.... Once it appears that another has in fact used the copyright as the source of his production, he has invaded the author's rights. It is no excuse that in so doing his memory has played him a trick."). In Fred Fisher, Judge Hand found that the similarities between the songs "amount[ed] to identity" and that the infringement had occurred "probably unconsciously, [based on] what he had certainly often heard only a short time before." Id. at 147.

50. Carissa L. Alden, Note, A Proposal to Replace the Subconscious Copying Doctrine, 29 CARDOZO L. REV. 1729 (2008). 
conception was fully communicated to the later patent claimant (the "deriver"). ${ }^{51}$

Proof of prior conception comes with all the rigmarole of a patent priority contest, including a heavy burden of proof and a demanding corroboration requirement. ${ }^{52}$ These issues are some of the reasons that patent interferences under the 1952 Patent Act are so notoriously complex; they in no small measure contributed to the scrapping of the 1952 Act's "first to invent" standard in favor of a (modified) first-to-file system under the America Invents Act of 2011. ${ }^{53}$

Once the "derivee" proves prior conception, he then faces the daunting task of showing full communication of the invention to the deriver. Many derivation cases end right here. The standard is strict: the full invention must be communicated to prove derivation. ${ }^{54}$ Thus courts decline to find derivation when the proven details of the alleged derivee's communication diverge from the claims of the alleged deriver's patent. ${ }^{55}$

More generally, the $\S 102(\mathrm{f})$ cases show many instances where a prior inventor taught or influenced later researchers in ways that fall short of actual legal derivation. For example, in one case a Florida State University research lab was shown to have developed a method for making a class of chemical compounds. Another research group, working at a company called American Biosciences, later patented similar compounds using the

51. Creative Compounds, LLC v. Starmark Lab., 651 F.3d 1303, 1313 (Fed. Cir. 2011) ("In order to establish derivation, [a challenger to the validity of a patent] was required to "prove both prior conception of the invention by another and communication of that conception to the patentee.' Eaton Corp. v. Rockwell Int'l Corp., 323 F.3d 1332, 1334 (Fed. Cir. 2003).”).

52. Egnot v. Looker, 387 F.2d 680 (C.C.P.A. 1967); Williams v. Clemons, 19 F.2d 798 (D.C. Cir. 1927) (applying the strict corroboration requirement from prior invention cases such as The Barbed Wire Patent, 143 U.S. 275, 285 (1892) to derivation cases); see also Price v. Symsek, 988 F.2d 1187 (Fed. Cir. 1993) (an inventor's testimony, standing alone, cannot support a claim of derivation under $§ 102(\mathrm{f})$ ).

53. See Robert P. Merges \& John F. Duffy, Patent LaW and Policy: Cases AND MATERIALS at 341-44 (6th ed. 2012).

54. See, e.g., Hedgewick v. Akers, 497 F.2d 905, 908 (C.C.P.A. 1974) ("The issue of derivation is one of fact, and the party asserting derivation has the burden of proof. ... Derivation is shown by a prior, complete conception of the claimed subject matter and communication of the complete conception to the party charged with derivation.") (emphasis added); see also International Rectifier Corp. v. IXYS Corp., 361 F.3d 1363, 1376-77 (Fed. Cir. 2004) (no derivation because no proof of prior conception of invention identical to the one claimed).

55. Pentech Intern., Inc. v. Hayduchok, 1990 WL 180579, at *8 (S.D.N.Y. Nov. 12, 1990) (Leval, J.) ("Because I find that plaintiff has not proven prior invention of the patented technology, the derivation challenge fails. There has not been an adequate showing that the Reinol formulas were identical to those ... in the patent."). 
Florida State method. ${ }^{56}$ One inventor on the American Bioscience research team had formerly worked in the Florida State lab that developed the chemical method. Other inventors on the team attended a conference at which the head of the Florida State lab presented. Even so, the court held that there was no improper derivation, and no need to add any Florida State inventor to the American Bioscience patent. One reason given was that no one in the Florida State lab directly communicated the specific compounds claimed in the American Biosciences patent. ${ }^{57}$ Under very similar facts, courts have refused to find co-inventorship in addition to rejecting charges of derivation. ${ }^{58}$

Thus, the stringency of proof required for derivation limits this doctrine to a small number of cases. The patent challenger asserting derivation must demonstrate immediate, direct, usually face-to-face communication. Without something more-without a liberal rule covering other sorts of influences and communications-many instances of learning from another would never be detected or proven in the patent system. The absolute liability standard again serves as a response to the unfairness that would result in its absence.

56. Bd. of Educ. ex rel. Florida State Univ. v. Am. Bioscience, Inc., 333 F.3d 1330 (Fed. Cir. 2003) [hereinafter Bd. Of Educ.]

57. Okwedy v. Molinari, 333 F.3d 339, 342 (2d Cir. 2003).

58. See, e.g., Cook Biotech Inc. v. ACell, Inc., 460 F.3d 1365 (Fed. Cir. 2006) (Evidence that alleged co-inventor discussed technique with named inventor on patent was not sufficient to create a genuine issue of material fact "as to whether [the alleged coinventor] 'contributed to the conception of the claimed invention...' by sharing his knowledge of [the claimed technique], some of which is reflected in [a document authored by the alleged co-inventor]."). Professor Chisum discusses cases where a later inventor builds on the published work of an earlier inventor, but there is no coordination between the two; there can be no joint invention under the Patent Act in such cases:

$[\mathrm{T}]$ here can be joint invention of subject matter $\mathrm{Y}$ when (1) inventor A works on a problem up to the stage X; (2) A turns the partial solution over to inventor B in a remote but nonpublic manner; and (3) B uses $\mathrm{X}$ to perfect $\mathrm{Y}$. However, there can be no such joint invention when $\mathrm{A}$ develops $\mathrm{X}$ and then publishes or otherwise makes it known and $\mathrm{B}$ independently uses $\mathrm{X}$ to develop Y.

Donald Chisum, Chisum on PATEnTs § 2.02[2][f] (citing B.J. Serv. Co. v. Halliburton Energy Serv., Inc., 338 F.3d 1368 (Fed. Cir. 2003) (later inventor claimed method of using material invented by earlier inventor; no evidence of any collaboration between them; so no joint invention). It follows that granting co-inventorship status is not a viable way to capture the influence of an earlier contributor when the later contributor is influenced, or learns from, the earlier contributor, but does not, strictly speaking, copy from her. Where appropriate, patent infringement liability is the only way to capture this type of contribution. 
b) The Tricky Case of Partial Derivation

Requiring proof of copying means requiring proof that an accused infringer intentionally duplicated someone else's entire invention. ${ }^{59}$ But what if an accused infringer copies less than an entire invention? That cannot comfortably be called copying-even if what is borrowed is the key technological insight that adds value to the patented invention and the accused infringer's product. One rationale for dispensing with proof of copying, then, is to provide compensation when what has been copied is less than an entire invention.

Derivation law again provides some insight. To invalidate a patent under $\S 102(\mathrm{f})$, one generally must show that the patentee was told about the complete invention he or she later claimed. However, courts have found that $\S 102(\mathrm{f})$ prior art is relevant under the nonobviousness provision, $\S 103$. Consequently, a partial deriver will not receive a patent if his or her claim is obvious in light of the combination of the derivee's $\S 102(\mathrm{f})$ disclosure and other prior art. ${ }^{60}$ But a partial deriver will receive a patent if he adds enough to make his claim nonobvious in light of what was disclosed by the derivee. In this scenario, where the deriver adds a nonobvious contribution to information acquired from the derivee, absolute liability protects the valuable information disclosed by the derivee. The fact that the deriver in this situation added something valuable does not detract from the point that he or she learned something of significant value from the derivee. The deriver might even obtain a patent for his or her valuable variant, but this patent does not protect the deriver from liability for infringing the derivee's patent. Such a "blocking patent" situation leaves both contributors with a property right. But absolute liability protects the contribution of the derivee.

Infringement doctrine protects the derivee when $\S 102(\mathrm{f})$ does not. That is because infringement doctrine dispenses with the need to show complete copying, while $\S 102(\mathrm{f})$ requires it. To see how separate

59. It has been observed that the America Invents Act of 2011, in eliminating $\S 102$ (f) on derivation, runs the risk of requiring the PTO to issue many patents on inventions that are at least partially derived from others. See Josh D. Sarnoff, Derivation and Prior Art Problems with the New Patent Act, 2011 PATENTLY-O PAT. L.J. 12, 16 n. 13 ("[A] non-obvious variant of a derived invention may or may not be severable from the original invention" ... [And] a patented non-obvious variant may not infringe the originator's invention, but if it does, it may become a blocking patent (if the original invention issues as a patent)"). Once again, absolute infringement liability allows us to reach through the act of copying and impose liability where the derivee learned something substantial and important.

60. See Oddzon Prod., Inc. v. Just Toys, Inc., 122 F.3d 1396 (Fed. Cir. 1997). 
patenting of an invention protects an inventor when invalidity of the deriver's patent does not, it is important to understand that there are really two disparate types of partial derivation. In one, the deriver appropriates the entirety of an earlier inventor's contribution-lifts it whole hog in other words - and then, in addition to the entire prior earlier invention, adds other elements or features. Infringement law easily addresses this "plus" type of partial derivation. As long as the deriver copied all of a prior invention, and the deriver's marketed product includes that prior invention in its entirety, what other features the deriver may have added are irrelevant. A court will find patent infringement. ${ }^{61}$ So in cases of "plus" type partial derivation, infringement liability will follow regardless of whether patent law requires proof of copying. A deriver may also be able to prove that the derivee's patent is invalid under $\S 102(\mathrm{f})$ in such a case. The key will be whether the deriver can show that it communicated the entire invention to the derivee, and that the derivee copied it in making its own invention.

This is not true in the second type of cases, however. In these cases $\S 102(\mathrm{f})$ is no help to the derivee; the only hope is for the derivee to have its own patent. In these cases the deriver copies only a portion of a derivee's invention. This "fractional" type of derivation will not result in invalidity under $\S 102(\mathrm{f}) .^{62}$ But patent infringement under absolute

61. Technically, liability in the case of a "plus" type infringement depends on how the derivee/patentee drafts her claims. For "plus" type infringement to give rise to liability, the patentee must claim her invention in a way that contemplates liability even when the infringer adds components or elements beyond what was derived from the derivee. Such claims are said to be "open" claims, and they usually include the word "comprising" in them. See Merges \& Duffy, supra note 53, at 28. Because open claims are broader, they are preferred by patent drafters. And empirically, they are much more common than "closed" claims, which usually include the limiting term of art "consisting of." A rough estimate of the ratio of open ("comprised") claims to closed ("consisting of") claims can be made based on patents issued in 2014. In that year, there were 294,427 patents issued that included "comprising" in the claims, and only 5,060 that included the words "consisting of." These data were obtained using the www.uspto.gov patent search website. Note that the "consisting of" patent count was constructed of (1) all patents with "consisting of" in the claims, minus (2) all patents that included the phrase "group consisting of." This latter claim format, called a Markush group by patent drafters, is fairly common, so including patents with this language in the claims badly overstates the number of patents with closed claims. Having said that, it should be apparent that there will be a small number of patents that include "consisting of" in a limiting sense, together with claims that include the Markush terminology "group consisting of." Put simply, the method used for the count reported here may slightly undercount the number of patents that include "consisting of" in their claim language.

62. See, e.g., Bd. of Educ., supra note 56 (alleged co-inventors, and hence derivees, would have been properly named as co-inventors on deriver's original broad claims; but 
liability might apply in such a case. If the deriver is found to be using something that meets all the elements of the derivee's patent claim, infringement will follow-even if the derivee cannot prove that every element in its claim was communicated to the deriver. In other words, it does not matter what portion of an invention is copied. Absolute liability means that the infringer will be liable when he or she adds one or more elements to the portion of an invention derived from the patentee. Absolute liability in this sense fills in the gaps between the derived portion of an invention and the full version claimed in the deriver's patent.

To summarize: these cases of patent validity under $\S 102(\mathrm{f})$ illustrate several points about liability for patent infringement. In every case of "partial derivation," the party arguing invalidity under $\S 102(\mathrm{f})$ would be unable to invalidate the deriver's patent. This result stems from the rule requiring the derived invention as claimed to incorporate the complete invention as disclosed by the derivee. But when we assume that the derivee in these cases also has a patent, in addition to the one held by the deriver (and whose validity is in doubt under $\S 102(\mathrm{f})$ ), we see how absolute liability helps the derivee. Derivation doctrine precludes a derivee from invalidating a deriver's patent if the deriver's claims cover something other than the complete invention communicated by the derivee, or a nonobvious variant of that communicated invention. In this situation, however, because patent law does not require proof of copying, the derivee with a patent covering his or her invention can successfully assert it against the deriver. Disclosure of less than the full invention is irrelevant to infringement liability. Indeed, there is no need to prove any disclosure at all-that is the purpose of absolute liability. Again, by dispensing with proof of copying, the law will capture cases where someone acquired valuable information from someone else, even though the details of the borrowing fall short of complete "copying."

Those who want patent law to require proof of copying for infringement liability might argue that infringement is no less serious an

they did not need to be added as co-inventors on deriver's subsequent narrower claims, despite the fact that evidence showed the deriver learned general techniques for making claimed compounds from the derivee). Cf. Alexander v. Williams, 342 F.2d 466 (C.C.P.A. 1965) (Invention had two elements, $\mathrm{X}$ and $\mathrm{Y}$; inventor A communicated element $\mathrm{X}$ to inventor $\mathrm{B}$, and $\mathrm{B}$ thereupon conceived of element $\mathrm{Y}$. The court held that $\mathrm{B}$ had not established priority in an interference (priority contest) between $\mathrm{A}$ and $\mathrm{B}$, because of A's prior communication of element X). Note that in Alexander, if inventor B made, used or sold a product that included all the elements of one of A's patent claims, B would infringe, despite the fact that B only partially derived its product from A's prior invention. 
offense than derivation - and therefore that the stringency of proof should be the same in both cases. If the deriver is a "thief," then so is the infringer. Under this argument, the "thief" label should not be attached lightly; it should require equal levels of proof for both derivation and infringement. By placing one's name on a patent, one does not deserve worse treatment than when incorporating a patented invention in a commercial product. But in any event, we can use the differences in the two areas of law to make an interesting point. Derivation requires stringent proof - and in the process, situations where researcher A clearly teaches, influences, and contributes to B's research do not always amount to derivation under $\S 102(\mathrm{f})$. But the same levels of influence, teaching, and contribution may permit $\mathrm{A}$, if he or she has a patent, to successfully sue $B$ for patent infringement. Patent law in effect makes it easy for a patentee to capture instances of less-than-complete copying. But the law makes it hard for a person to invalidate another's patent under the same circumstances. The derivation cases thus show, first, that proof of copying is difficult. And second, they may help to show why, for purposes of infringement, the law dispenses with proof of copying altogether. Even where $\mathrm{B}$ incorporates less than A's full invention, the law may want to compensate $\mathrm{A}$ for the portion of its invention that $\mathrm{B}$ did acquire. It does this by dispensing with the need for proof of full acquisition (copying). The law presumes, in effect, that if $B$ is selling a commercial product that is covered by one or more claims in A's patent, B has learned enough from A that patent infringement liability ought to follow. Both the difficulty of proving full copying (the partial derivation cases), and the plausible fairness of requiring compensation for less-than-complete acquisition, argue in favor of this result.

\section{From COPYING TO ACQUIRING}

A few times now, this Article has argued that the transfer of technological information from one researcher to another occurs along a spectrum of related acts. There is deliberate copying of a complete invention. Then there is "copying plus," i.e., deliberate copying plus new contributions from the copyist. But then there are also less conscious, less blatant ways that a prior inventor can communicate valuable information to other researchers. The field of diffusion studies names them well: they are mechanisms by which an original idea is spread around a group of interested people. When one of these people learns from the prior inventor, or borrows from what is taught, his or her act is usually not referred to as copying. Diffusion studies bear this out. They analyze the flow of information through a technical community, rather than discrete 
acts of learning, duplication, or copying. Implicitly, the field understands that ideas percolate and spread through a wide variety of mechanisms.

In a way, the absolute liability standard in patent law reflects this way of thinking. It dispenses with the need to prove actual copying. And in so doing, it leaves room for all manner of information transmission. Patent law tries to capture a wide spectrum of ways an inventor might teach or influence others in a technical community. It eschews reliance on one discrete endpoint in the spectrum of influence (i.e., actual copying) by crediting an inventor when his or her valuable ideas have influenced or taught others in ways that are indirect, subtle, and hard to prove. Patent law, in other words, attaches liability for various types of information acquisition, and not just for direct copying.

There are many reasons to avoid outright theft of another's invention: trade secret protection; derivation proceedings in patent law; and concern for willful infringement (with the potential for treble damages). But it takes a great deal of solid evidence to establish any of these bases of liability. There are several species of idea acquisition that fall well short of the high standards required in these areas, and these species ought to give rise to legal liability because the acquisition involved is nevertheless significant. These types of borrowings do not trigger legal liability under derivation, trade secrecy, and the like. They are, in effect, the unique species of acquisition that are exclusively protected against by patent law's general standard of absolute liability.

Several distinct types of acquisition compose this residual category. One is borrowing that falls short of explicit, intentional copying. This runs the gamut from partial, unacknowledged borrowing; to inadvertent borrowing; to completely subconscious (and one might even say unintended) acquisition. The studies described earlier capture these categories well. For each, proof of deliberate copying will not be possible because no deliberate copying occurred in the first place.

The second type involves partial acquisition-borrowing of less than a full, coherent inventive concept. As described earlier, patent law's derivation defense does not reach this activity. But absolute liability does. By dispensing with proof of copying, it covers the case where a person acquires key ideas from someone who later obtains a patent.

To generalize, then, absolute liability ends up covering residual categories of information acquisition. It makes borrowers liable when they have borrowed, but (1) the patentee cannot prove borrowing; (2) the borrowing was inadvertent; or (3) the borrowing was partial, not complete. Because acquisition in these instances should arguably still give rise to liability, absolute liability steps in. It covers instances where there has been 
some significant degree of idea transmission, but the law would not otherwise impose liability.

Implicit in this formulation is a preference for the law to favor the information-supplier in these scenarios. But why should we be so solicitous of this person, at the expense of others who merely "learn" or "acquire information" from him or her? Admittedly, this is perhaps a weak point of this Article's argument. The assumption here is that, where possible, we want to credit (and compensate) originators of information, even when proof of learning or acquisition is difficult to come by. This argument assumes a bias in favor of those who originate information, and upon whose work others build. To make a full case in favor of absolute liability would require extensive proof that this bias in favor of idea originators is warranted. This might prove difficult, as the free flow of information is a point on which much of the argument here is built. If absolute liability encourages the free flow of information, then why not eliminate liability completely in more cases, and thereby encourage information flow even more? It is enough, in keeping with the spirit of this Article, to put forth a set of arguments in favor of absolute liability. The point is merely to put something positive on the other side of a scale that has been tipping heavily in favor of eliminating absolute liability in recent years. The full case would be hard; so we begin with an easier task - saying a few kind words in favor of absolute liability. It is a key assumption in this argument that we want to favor idea originators. Perhaps further empirical research will illuminate the issue. In the meantime, it is best to proceed on the basis that rewarding idea originators is a good idea, and note that absolute liability is a good way of achieving that goal.

\section{EXCESS PRECAUTION:THE COST OF REQUIRING PROOF OF COPYING}

The first argument was that copying is hard to prove, and that it is indeed more of a spectrum of related behaviors than a single discrete event. The second argument is that if the law requires proof of copying, many firms may well invest in elaborate systems to disprove that copying has taken place-and that these systems are bad for society. When IP owners must prove copying, people who are likely to be targeted for lawsuits will take steps to keep "outside" information from entering their organizations. This cuts down on the flow of information across 
organizations, which in turn suppresses the rate at which information spreads in a field or industry. ${ }^{63}$

Paradoxically perhaps, a strict liability standard actually encourages communication. Under strict liability, who communicated what to whom, and when, are all irrelevant. If the volume of communication is irrelevant to one's chances of liability, then there is no patent-related disincentive to communicate. Talking and sharing freely have no identifiable cost for purposes of patent law. But there are benefits. So people and companies tend to share.

\section{A. The Tort Theory Perspective}

One way to capture this thought is to describe the copying rule in patent law in terms familiar to students of tort law. To do so, this Article treats the accessing of technical information produced by third parties as a potentially risky activity. It is commonplace for a researcher from Company A to read a technical paper written by researchers at Company $\mathrm{B}$, and incorporate the information from B's paper into a product later sold by $A$. If $B$ patents the information published in its technical paper, A may find itself liable for patent infringement. From the point of view of potential liability, A's reading of B's technical paper creates a risk of harm to $\mathrm{B}$. Of course, B may choose not to patent. Or A's product might benefit from B's information, yet not meet all the elements of any claim in B's patent. Which means that in reality, $A$ will have to analyze the situation taking into account both A's chances of infringement and B's "propensity to patent."

Once things are framed this way, we can look to tort theory for guidance on the best way to handle this risk. Before doing so, I have two quick points to make. First, I want to recognize that the "risk" discussed here is different from the types of risks that are usually associated with torts. Tort law typically concerns physical risks, or at least risks to interests that seem quite basic. Car accidents are the classic example. When

63. One response to these costs is simple and drastic: weaken IP rights, prevent them from being applied in some fields, or perhaps do away with them altogether. See, e.g., KAL RAUSTIALA \& CHRISTOPHER SPRIGMAN, THE KNOCKOFF ECONOMY (2012) (describing industries that thrive despite the absence of effective IP rights); MICHELE BOLDRIN \& DAVID K. LEVINE, AgAinst InTELlECTUAL MONOPOLY (2008) (general case against IP rights); See also Robert P. Merges, Economics of Intellectual Property Law, in OXFORD HANDBOOK OF LAW AND ECONOMICS (Francesco Parisi, ed., forthcoming), http://ssrn.com/abstract=2412251 (reviewing positive economic case for IP rights, and noting limitations of research showing that creativity flourishes in some industries despite the absence of IP rights). 
discussing optimal tort rules, it is plain to everyone that cost-effective minimization of the risk of physical injury is an important, or even essential, interest that society ought to care about a great deal. Patent infringement is entirely different. It does not involve physical harm. Moreover, it does not seem to involve an interest that is nearly as important or essential as those at stake in many tort cases. Indeed, it might be argued that the "harm" and "risk" of patent infringement is more the product of a legal policy than an affront to a central and personal interest such as physical integrity.

The answer to this objection is twofold. It requires that we recognize the importance of innovation to economic well-being, and of economic well-being to other important social values such as stability and opportunities for self-advancement. The interests involved, in other words, are important ones. And it requires an acknowledgement that though tort law canonically deals with physical injuries, it also embraces a wide spectrum of economic injuries. Perhaps some of the intuitive force of tort law is weakened when it concerns injuries and risks that are purely economic. But because tort law provides powerful tools for thinking about risks and harms, it is worth moving forward with an analysis of patent infringement from a tort-centric perspective. Although the interest at stake in patent infringement may seem more "socially constructed," and somehow less "essential," it is nevertheless an important interest. And it is therefore worth looking at how harms to that interest are, and should, be handled by the law.

Another fundamental objection to the basic approach used here has to do with the nature of the "harmful activity." As previously stated, the risk or harm we are talking about occurs when A uses B's technical information. This often begins with A reading or otherwise learning about technical research that $\mathrm{B}$ has performed. Some readers may balk at a framework that takes the acts of reading or learning as a "harm" or "injury." It may seem wrongheaded, offensive, or even vaguely unconstitutional to treat reading as a potentially harmful act. While this view deserves some sympathy, consider also two important points. One is that reading alone never creates infringement liability; patent infringement occurs when an infringer makes, uses, or sells a product incorporating the patented invention. So it is the use of the acquired information that triggers legal liability. And second, there are other areas of law where simply accessing information is seen as a harm. Trade secret misappropriation, insider trading, and access via computer hacking are examples. Further afield are national security-related offenses. The point is that despite the general disposition of society and our legal system, which 
broadly and generally favors free and easy access to as much information as possible, there are situations where reading and learning about a particular piece of information can lead to legal liability.

Of course, even under absolute liability, one's chances of liability for infringement increase when one receives information from a source that will later obtain a patent. So it might be asked: why don't people currently screen out information they receive from sources that are likely to file for patents? Why don't they keep out information from "patent likely" sources, and allow in only information from "patent unlikely" sources? The response to this starts with two basic facts. First, the probability that infringement liability will follow directly from receiving and using any particular piece of information is quite low. The cost of screening information by source-of differentiating between information transmitters that are at high likelihood to later obtain patents versus those at low likelihood-would be quite high. And, crucially, keeping out information from a source that is likely to patent only reduces the chance of legal liability. If in-house researchers learn the same information from another source, or create it independently themselves, the company could still be liable. Screening outside information under the current rules eliminates one potential source of legal liability. But it cannot eliminate the threat of liability altogether because under the current rule, liability is independent of any particular source of information. Eliminating a particular source of information might help lower the risk of liability-but only to the extent that this particular source is unique, and only if in-house researchers will not duplicate the information from the source or receive it from somewhere else.

But a move away from absolute liability would significantly increase the payoff from screening. It would make it much harder to prove liability when a company systematically weeds out all information from external sources. Screening under today's absolute liability standard merely reduces the potential incidences of idea acquisition. It does not affect liability once information held by a particular outside source is either acquired elsewhere or is recreated in-house. This changes under an independent invention defense. The ability to escape liability by showing independent invention, in effect, makes in-house research completely safe from any risk of liability-assuming one can prove that no external information ever entered the research process. ${ }^{64}$ Liability follows only after proof that

64. To be precise, independent invention privileges (1) truly in-house research, as well as (2) externally acquired information for which there is no proof of access. The 
invention came from a particular source - an external researcher who later patented the information. Eliminate proof of access to this source, and you eliminate liability. Put another way, screening under independent invention does not just eliminate one source of duplicated information, it eliminates all risk of liability. It privileges in-house research, which happens to duplicate external information, by making it immune from legal liability. This creates a much bigger incentive to eliminate outside information. ${ }^{65}$

evidentiary burden of proving access to external information effectively renders impossible-to-prove external access the equivalent of in-house research.

65. To be specific: information from outside a firm can do one of three things. It can (1) bring general benefits, without increasing the risk that the recipient will infringe any patents owned by the sender of the information; (2) it can cause infringement, when the recipient copies it and would not have independently invented it; or (3) it can increase the risk of liability when the recipient does not copy it, by undermining the recipient's ability to prove that it independently invented. Under either legal rule-absolute liability or proof of copying/independent invention - the decision whether to screen information from outside the firm involves a tradeoff between (1) and (2). Because under the existing (absolute liability) rule, screening appears to be very rare, we can conclude that firms find (1) outweighs (2). My argument thus concerns the addition of (3) to the equation. Screening under a proof of copying/independent invention rule brings an additional benefit over the current situation. It eliminates liability in some cases where it cannot be eliminated under absolute liability. The magnitude of this marginal effect will determine whether my concern about extra screening is valid. The social welfare effects depend on two factors. First, the firm faced with the decision whether to screen or not must do its homework correctly. A crucial issue is how often external idea acquisition will lead to legal liability. If a firm overestimates this (which could well happen due to the high salience of very large patent damages in rare cases), it might decide to screen when that is not in fact efficient. Second, the firm might underestimate the lost value of external information. Firms so frequently disregard valuable external information that the phenomenon has a name: the "not invented here syndrome." See Ralph Katz \& Thomas J. Allen, Investigating the Not-Invented-Here (NIH) Syndrome: A Look at Performance, Tenure and Communication Patterns of 50 RED Project Groups, 12 RES. \& DEV. MGMT. 7 (1982). If the information that is screened out to reduce liability would have yielded large firm-level benefits (in the form of less duplication of effort, and the stimulation of improvements and variants that would have resulted if the in-house team had access to the external information), then screening may involve difficult-to-estimate, but very real costs. As a separate matter, it may be costly from a social point of view. Screening may reduce the incidences of external copying below the socially optimal level. This will occur when the screening firm does not bear all the costs of screening (e.g., its in-house team may miss out on the chance to build on external information that would be hard for the firm itself to capitalize on, but that would benefit society). It is exceedingly difficult to estimate these "lost potential social spillover costs" that occur when an in-house team is denied access to external information. All that can be said is that under current conditions, we observe that there is a very large volume of information sharing among researchers; and there are very large social spillovers from much organized research activity. We might well be loath to disturb the legal rules that produce this favorable equilibrium. 
This shift might be enough to change the behavior of firms- to move them to an aggressive use of information screening. It would still be true that the probability of infringement is low for each piece of information received, but the ability to eliminate liability in some cases by screening might make it a good idea to screen. Once again, efforts to reduce copying of information might make sense from the perspective of each individual firm, but would entail high social costs. Paradoxically, and against the weight of scholarship on this topic, requiring proof of copying might make duplicative effort more common, not less common. ${ }^{66}$

The logic is simple. People will invest in precautions against copying so long as the expected payoff from these investments exceeds the (probability-weighted) expected loss from patent infringement liability. ${ }^{67}$ They will ask only: is the potential cost of infringement payouts to prospective patentees greater or lesser than the cost of preventing copying? This prevention cost would include both the immediate costs of setting up and running a screening system, as well as the loss of value from not being able to use information that comes from patent-likely sources-with this latter cost itself being comprised of two components: (1) invention opportunities lost or forgone because of the absence of a key piece of information that would have come from outside, had it not been screened out; and (2) the added cost of recreating information in-house that would have been obtained for free from external sources, had screening not been imposed. From the point of view of a single research entity, if the sum of these prevention costs is lower than potential infringement payouts, then it should choose preventive screening. Given high damages awards in patent cases, this is entirely possible. ${ }^{6}$

66. The alert reader will note that here we are equating the requirement to prove copying with an independent invention defense. Of course, there is a subtle but perhaps important distinction between the two. Proof of copying puts the burden on the patentee to prove that the infringer copied. Independent invention puts the burden on the infringer to prove that it in effect did not copy - that it independently invented. In either case, the accused infringer would benefit from being able to prove that it did not have access to-and so could not have copied-the patentee's invention. So in this sense they are equivalent.

67. This is a simple application of the Learned Hand negligence rule first set out in U.S. v. Carroll Towing, 159 F.2d 169, 172 (2d Cir. 1947) (L. Hand, J.). See generally Richard A. Posner, Instrumental and Noninstrumental Theories of Tort Law, 88 IND. L.J. 469, 469 (2013) (describing Hand formula).

68. Note that the torts analogy suggests a completely different approach to the copying question. As with other harms, the law seeks to affect the ex ante incentives of decision makers as a way to encourage just the "right" amount of harm. We typically care about the calculus of the decision maker whose activities create a risk of harm and who must choose how much to invest in precautions beforehand. So arguably, the real 
An individual research unit may well get it wrong when making the decision about investing in precautions. That is because not all the variables mentioned in the prior paragraph are equally salient to the average decision maker. Past patent infringement awards, for example, may stick out in a decision maker's mind; press accounts of whopping damage awards are fairly common, and they rarely mention that the reported damages are far in excess of averages or medians. At the same time, cost component (1) above-the cost of foregone invention opportunities that follows from screening out potentially valuable information - is very hard to measure, and may well fall victim to the wellknown propensity of research units to undervalue outside information. ${ }^{69}$ Likewise, it may be difficult for a firm to figure out which pieces of important information that came from in-house sources would have been instead received from outside in the absence of screening. This all adds up to a single point: the benefits of preventive screening may be quite visible or salient, but the costs may be hard to fathom. And that implies excessive screening.

\section{B. How ABSOLUTE LiABILITY FEEDS THE INFORMATION COMMONS}

When looking carefully at the likely effects of requiring proof of copying, the hidden advantages of the status quo become apparent. The unseen truth about absolute liability is that it makes the source of information irrelevant. This makes it unnecessary for researchers to segregate the information they receive. Any researcher who invents something may be liable for patent infringement. It could happen if the researcher directly copies information. It could happen if he or she

requirement in patent law ought to be not copying per se, but negligent copying: copying that would have been avoided by a researcher exercising an ordinarily prudent standard of care. On this view, some copying would be expected and permissible; the only copying that would lead to liability would be negligent or inefficient copying-copying that took place because a researcher chose not to implement prudent screening in a given case. This might be hard for people in the patent system to accept; letting a copyist go free might seem outrageous. On the other hand, it might be argued that a copyist charged with infringement would be very unlikely to escape liability under the negligence standard, because-assuming a high correlation between detection of infringement and very serious economic harm-copyists hauled into court for infringement would rarely be able to show they took adequate precautions under the circumstances. An alternative theory, of course, is that copying an invention is a moral wrong and cannot be excused under an economic calculus. Cf. Posner, supra note 67, at 469 (explaining non-instrumental views of torts).

69. See discussion and sources cited supra note 65; Michael J. Meurer, Inventors, Entrepreneurs, and Intellectual Property Law, 45 HoUS. L. REV. 1201, 1215 n.55 (2008) (citing "not invented here" syndrome described in a research source). 
partially copies. It could happen if he or she inadvertently copies. And it could happen if he or she never copies at all-if an invention springs strictly and solely from his or her own inspiration. Absolute liability makes it completely irrelevant where the inspiration for an invention comes from. Put another way, there is nothing anyone can do about patent infringement liability. It just is.

Since there is nothing anyone can do about infringement liability, when it comes to the sources of technical information, no one does anything. And therein lies the great advantage. It makes very little sense to screen technical information; doing so will not reduce the chances of liability enough to make it worthwhile. (We know that for a fact because no one does it now.) What this means is that researchers can gather information from any and all sources. They can acquire, store up, and use information without regard to where it comes from or whether it will one day find its way into someone else's patent. Absolute liability provides a sort of umbrella of legal risk. Under this umbrella, which covers all research activity, it makes no sense to try to avoid legal liability. So no one does. The result is that information is shared and acquired rather freely. Indeed, because of the potential for a disclosing party to obtain a patent even after the information is disclosed, it might be said that the patent regime provides an almost ideal set of incentives to disclose technical information. The strange feature of absolute liability, then, is that because it is indiscriminate in fixing liability, it permits researchers to be indiscriminate in obtaining information from any and all sources. Who would have thought that?-absolute liability means that patent infringement can come out of nowhere. And that frees researchers to acquire information from everywhere.

But here is another thought: in mixed technological communitiesthose where some members abjure IP rights, and others systematically claim them-absolute liability might be a plus as well. This is because absolute liability removes the need to selectively screen contributions from the two types of community members, those committed to "open sharing" and those who believe in obtaining patents. On the assumption that technical information from a "pro-patent" member would more commonly lead to a later charge of infringement, community members might well erect barriers against information from pro-patent members. Not only would this reduce the total volume of technical information available to a community member, it would also be costly in and of itself. Technically trained researchers would have to be put in place to screen technical articles, conference presentations, and other sources of information. Each item would have to be labeled by source: pro-patent or non-patent. Only 
information coming from non-patent sources would be allowed through. This screening would be necessary because of the likelihood that a propatent source communicating technical information today will file for a patent on that information. So if the recipient incorporated the ideas in a communication into one of its own products, it would be potentially liable for patent infringement when a patent issued at some later time to the company from which the information originated. This type of screening would be expensive.

\section{PRIOR COMMERCIAL USE AND OTHER DOCTRINAL ALTERNATIVES}

In light of this research, two related issues deserve consideration. One is the new prior commercial use right, $\S 273$ of the America Invents Act of 2011 (AIA). The other is a set of scholarly suggestions for an independent invention defense.

\section{A. Prior Commercial Use: The Good and the Bad}

Under AIA $\S 273$, a person who uses certain inventions commercially more than one year before another applies for a patent may continue to use the invention despite issuance of a patent to the other person. ${ }^{70}$ This "prior commercial use" (PCU) defense is quite limited, however. First, of course, it only applies to patents issued after September 2011, when the AIA was passed. Second, the commercial use must be continuous during

70. The statute has an alternative one-year limit. The prior commercial use defense fails if the prior user cannot establish his or her use more than a year before the applicant filed. In addition, the defense fails if the prior user cannot prove use more than a year before the patent applicant first discloses his or her invention publicly, prior to filing. 35 U.S.C. $\S 273(\mathrm{a})(2)(\mathrm{A}),(\mathrm{B})(2012)$. The AIA's legislative history describes the purpose behind the prior commercial user defense:

Many countries include a more expansive prior-user rights regime within their first-to-file system. In the United States, this is particularly important to high-tech businesses that prefer not to patent every process or method that is part of their commercial operations. . . This narrow expansion of prior-user rights balances the interests of patent holders, including universities, against the legitimate concerns of businesses that want to avoid infringement suits relating to processes that they developed and used prior to another party acquiring related patents.

AMERICA InVEnTS ACT, H.R. REP. NO. 112-98, pt. 1, at 44 (2011). The reference to universities indicates the defense is not available for patents growing out of grant-funded university research. See 35 U.S.C. § 273(d)(5)(A) (2012); On parallel "public disclosure" provisions in the grace period under the AIA, see Robert P. Merges, Priority and Novelty Under the AIA, 27 BERKELEY TECH. L.J. 1023 (2012). 
the infringement period, which creates a risk that the defense will be limited based on abandonment. Third, there is a heavy burden of proof on the defendant-"clear and convincing evidence." Fourth, there is punishment for a defendant who "unreasonably" pleads the defensepayment of the plaintiffs attorney fees. Fifth, it applies only to process inventions and products "used in a manufacturing or other commercial process." 71

There is absolutely no indication that the contours of $\S 273$ were designed in light of the diffusion research described in this Article. Nevertheless, the many limitations of this new provision make at least some sense when viewed from this perspective. For one thing, the timing built into $§ 273$ makes it possible for the originator of an idea to file for a patent within one year of first publicly disclosing it, with the certain knowledge that anyone who borrows the idea will have to honor the inventor's patent. By the same token, anyone who files within a year of public disclosure, when met with evidence that someone else was indeed using the same idea more than a year before the inventor's filing date, can be confident that it is truly a case of independent invention. Moreover, the burden of proof required in the new provision eliminates the need for the inventor/patentee to prove copying. Given the general nature of diffusion, and the potential for inadvertent plagiarism, this may be a good thing. Idea duplication can be very subtle indeed, and it makes sense to put the burden on the party asserting independent invention to show affirmatively that all components of their research originated with them, or at any rate did not originate with the inventor/patentee. On the other hand, for reasons discussed in the next Section, the proof requirement entails some costs as well.

One reason to favor the AIA's PCU defense is that this defense furthers a valuable policy goal beyond simply defending independent invention. The key is its emphasis on use. To qualify, one must not only invent earlier than a patentee who asserts a patent, one must also use the invention in a positive and constructive way. In light of what we know about the incidence of copying, the defense makes sense. First, the conservative timing requirements make it less likely that one who asserts the defense will have actually learned something crucial, at an earlier date, from the researcher who later obtains a patent. Second, even where learning takes place, the defense recognizes the value of rapid implementation. One who learns from another researcher-but also

71. 35 U.S.C. § 273(a) (2012). 
applies the learned information quickly in a commercial manner-makes an independent contribution to society. The defense recognizes this contribution, even when one learns from a researcher that later obtains a patent. ${ }^{72}$ It could even be argued that the emphasis on commercial use in $\S 273$ harkens back to an earlier era in U.S. patent law when the courts favored active implementation over the mere pursuit of legal rights. ${ }^{73}$

As previously suggested, PCU is a rather limited defense under the AIA. The diffusion research emphasized earlier can be read to support this, implying that remote researchers may subtly influence the ideas of others, in ways that are difficult to trace and document. Placing the burden of proving PCU on the defendant can be seen as a reflection of this. It might be defended this way: we place the burden of proving independent invention on the accused infringer because the evidence of independent invention is close at hand and easy for that party to pull together. Proof of copying, on the other hand, would be far more difficult for the patentee to produce. The evidence may be buried deep within the files and records of the accused infringer, making it hard for the patentee to reconstruct, through discovered documents and testimony, the chain of

72. For an argument that the prior commercial user defense represents a boon to domestic U.S. manufacturers, see Martin Gomez, Manufacturing, Please Come Home: How ALA's Prior User Right Could be the American Economy's Savior, 13 U.C. DAVIS BUS. L.J. 61 (2012). It should be noted that while this student author may be right, experience with overseas patent systems has shown that prior user rights are seldom used as an effective defense, at least in reported infringement cases. See, e.g., Pierre Jean Hubert, The Prior User Right of H.R. 400: A Careful Balancing of Competing Interests, 14 SANTA Clara COMPUTER \& High TECH. L.J. 189, 213 (1998) ("[T]he limited data available relating to operation of the prior user right in foreign countries suggests the incidence of prior user right problems which would arise in practice in the United States would be very small."); Keith M. Kupferschmid, Prior User Rights: The Inventor's Lottery Ticket, 21 AIPLA Q.J. 213, 223-26 (1993) ("[P]rior user right litigation is minimal in countries presently having the right[.] [I]t is safe to conclude that there should be an extremely small number of prior user rights cases in the United States.").

73. The now-discredited "paper patent" doctrine is an example of this. See Robert P. Merges, From "Paper Patents" to The Paper Bag Case: Economic Change and Patent Doctrine, 1870-1910, (Working Paper, April, 2013, on file with BTLJ) (arguing that nineteenth-century patent doctrine is a good example of general nineteenth-century thinking which encouraged the "release of entrepreneurial energy", a phrase made famous by the legal historian J. Willard Hurst); see also J.W. HURST, LAW AND THE CONDITIONS OF FREEDOM IN THE NINETEENTH-CENTURY UNITED STATES, at 3-32 (1956). Hurst elaborates this theme in his monumental book, J.W. HURST, LAW AND ECONOMIC GROWTH: THE LEGAL History OF THE LUMBER INDUSTRY IN WisCONSIN, 1836-1915, at 358 (1964) ("Nineteenth century public policy in the United States generally favored action and the venture of capital in production."). 
events by which the patentee's invention made its way into the infringer's product design.

First, the good news. The emphasis in the AIA is on use, not invention. Whether the accused infringer learned of an idea or a new way of doing something from the patentee does not matter. All that matters is use - a much more tractable issue of proof. It might be argued that this emphasis on use also returns the patent system to an emphasis on implementation that has been lost or disregarded in recent years. In the nineteenth century, the "paper patent" doctrine and other rules disfavored patents that were never actually implemented or put into practice. ${ }^{74}$ Arguably, a rule centered on proof of actual commercial use represents a partial return to the spirit of these nineteenth century rules. What matters, again, is practical use, and not just clever claim drafting and timely filing.

However, the PCU defense may not, in the end, make anyone very happy. For patentees, the fact that liability hinges on use may seem unfair. An infringer can indeed learn of an intriguing idea, and as long as it acts well before the inventor takes action (by filing or disclosing), the infringer is off the hook. For infringers, the stringent requirements of the PCU may prove quite burdensome. The records and evidence mentioned earlier may be difficult to assemble. In addition infringers may find it difficult to meet the stringent burden of proof. And above all, the defense applies only to process inventions and products "used in a manufacturing or other commercial process." ${ }^{75}$ It could be that the PCU in the U.S. will be doomed to the same fate it has experienced in other jurisdictions-a good defense in theory, but one that rarely proves effective in practice.

\section{B. Alternative “Middle Ground” Rules}

Thus far, this Article attempts to make a case for the absolute liability rule in patent law. Even so, at several points we have seen that this rule sometimes produces unfair outcomes. This Section briefly considers some in-between rules that have some of the positive features of the AIA's PCU defense, but that still fall short of a full and true independent invention defense.

First, consider the independent invention defense proposed by legal scholar Samson Vermont. Vermont's defense, styled a "reinvention defense," would attach prior to the time when a patented invention was widely publicized. In other words, actual or constructive notice of the

74. See Merges, supra note 73.

75. 35 U.S.C. § 273(a) (2012). 
existence of the patent would cut off the possibility of an independent invention defense. This constructive notice rule would obviously change the current rule of absolute liability, but only in cases where a reinventor had actual or constructive notice of a patented invention. As Vermont explains it:

Publication that would likely satisfy the standard for purposes of constructive notice includes English-language publication in an issued patent, a published patent application, publication in a mainstream scientific journal, or publication via presentation at a conference open to the relevant public. Note that, even with the stricter standard, an unavoidable evil of letting constructive notice shut the reinvention window is that legitimate reinventors who look for but never see the first inventor's good faith publication will nonetheless lose the defense if they fail to complete reinvention before the date of that publication. ${ }^{76}$

Vermont's broad dissemination requirement is close to the PCU defense of $\S 273$ in several respects. Although the PCU defense relies less on concepts of notice, intending instead to reward the application or commercialization of technology, a technology that has been commercialized is more likely to come to the attention of researchers and competitors. Therefore, commercialization will often (though not always) be correlated with dissemination. Even when it is not, dissemination and commercialization each serve a positive purpose-which means that both the Vermont proposal and the PCU alter absolute liability in ways that enhance social welfare. They are, as a result, similar at least in the broad sense of deviating from absolute liability only when doing so promotes an important policy.

A similar proposal by Roger Blair and Tom Cotter calls for infringement liability only for what they call "idle patents." ${ }^{77}$ Their primary motive is to reduce the patent search costs of a person or company that wants to market a new product. In this sense, their proposal is essentially a tort setup-patent infringement is a harm, and they seek to minimize the social welfare costs stemming from that harm. For patents in active use, society benefits by active deployment of the underlying technology. But no such benefit accrues in the case of "idle patents." So for

76. Samson Vermont, Independent Invention as a Defense to Patent Infringement, 105 MicH. L. REV. 475, 487 (2006).

77. See Roger D. Blair \& Thomas F. Cotter, Strict Liability and Its Alternatives in Patent Law, 17 BERKELEY TECH. L.J. 799 (2002). 
"idle patents," liability would require proof of actual notice to the infringer.

Both proposals have merit. Vermont's reinvention defense protects infringers from incurring liability when a patent is very difficult to discover in advance. It would also, if adopted, incentivize patent owners to widely disseminate information about their inventions. The Blair and Cotter proposal shares an important feature of the PCU defense of the AIA: an emphasis on applying technology rather than merely stockpiling patents. Varying liability standards according to whether patented technology is "in use" or "idle" would reward active deployment, much as rewarding "commercial use" with a defense against infringement.

In many ways these proposals would bring patent law closer to copyright with respect to proof of copying. Recall that the "access" requirement in proving copyright infringement often boils down to proof of an "opportunity to copy." The wide dissemination aspect of the Vermont proposal is quite similar; obviously an invention that is widely disseminated provides a greater opportunity to copy. Likewise, when Blair and Cotter speak of rewarding active deployment of technology, they in effect make it much more likely that a prospective infringer can discover the existence of a patent-on the theory that competitors are more likely to investigate the patent status of a technology when that technology has been put into practice.

Taken together, these two proposals present something of a middle ground as regards the patent liability standard. They are well short of requiring direct proof of copying, of course. But they also go well beyond absolute liability. They call for the patentee to establish facts that show it was quite possible the infringer learned or could have learned of the patented invention from the patent owner. I would call this a "plausible mechanism" requirement. Under it, the patentee would have to show not only that the infringer made, used, or sold an invention falling within one or more of the patentee's claims, the patentee would have to establish a "plausible mechanism" through which the invention might have been transmitted from the patentee to the infringer. In the case of a very obscure invention, one that had not been widely disseminated or deployed, proving a plausible mechanism would be difficult. Proof of actual, direct copying would of course suffice. Short of this, perhaps some idiosyncratic facts could be established - a plausible chain of communication, for example, extending from the patentee to the infringer. In the absence of any such facts, however, there would be no liability for patent infringement. 


\section{CONCLUSION}

Absolute liability dispenses with the need to prove often-complex facts. A right holder proves a violation; liability follows. The best defense of patent law's absolute liability rule-which eliminates any opportunity for an infringer to argue independent invention-makes a virtue of this stripped-down liability standard.

In some ways, what this Article has been arguing parallels the famous Fuller and Perdue explanation of the importance of reliance in contract law. For them, you might recall, the doctrine of consideration embodies a deep commitment to the protection of the "reliance interest" among contracting parties. Reliance is so important, they said, that consideration doctrine had evolved to eliminate the need for a party to actually prove it. In their words, judges had decided that in contract law: "To encourage reliance we must... dispense with its proof." ${ }^{\prime 8}$ The equivalent I am suggesting would say instead: To encourage disclosure and diffusion in general, patent law, for purposes of establishing liability, dispenses with its proof. By making proof of disclosure irrelevant, patent law eliminates liability-proofing strategies that might well isolate researchers much more than is good for them, or for us.

If the influence of an earlier inventor could be easily ruled out, and if an independent invention defense caused few distortions in the way research is conducted, an independent invention defense would be a fine thing. But neither point has been established. The many and subtle ways that earlier inventors can influence later ones means that absolute liability will, in important cases, lead to the fair outcome. And the ability to show independent invention makes it more desirable to screen out external sources of information. The likely result-research groups working on isolated "islands"-would significantly undermine the free flow of information amongst members of technical communities. The irony is that an exacting standard of liability means there is little reason to attempt reducing liability by increasing the degree of isolation. Researchers are thus in a sense united under the umbrella of absolute liability. And the sharing of information is encouraged because there are good reasons to learn from one another, but limited payoffs from increasing isolation. The whole thing sounds counterintuitive, paradoxical even. Yet it is true. Strong liability reduces the barriers to information flow among researchers. Before digging into it, who would have thought that?

78. Lon L. Fuller \& William R. Perdue, Jr., The Reliance Interest in Contract Damages: 1, 46 YALE L.J. 52, 62 (1936). 